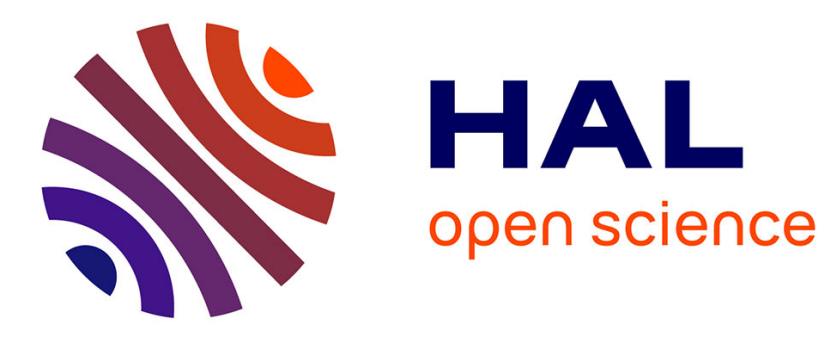

\title{
Stabilization of dichalcogenide ligands in the coordination sphere of a ruthenium system
}

Koushik Saha, Sourav Gayen, Urminder Kaur, Thierry Roisnel, Sundargopal Ghosh

\section{- To cite this version:}

Koushik Saha, Sourav Gayen, Urminder Kaur, Thierry Roisnel, Sundargopal Ghosh. Stabilization of dichalcogenide ligands in the coordination sphere of a ruthenium system. Dalton Transactions, 2021, 50 (37), pp.12990-13001. 10.1039/d1dt01614h . hal-03331393

\section{HAL Id: hal-03331393 https://hal.science/hal-03331393}

Submitted on 16 Sep 2021

HAL is a multi-disciplinary open access archive for the deposit and dissemination of scientific research documents, whether they are published or not. The documents may come from teaching and research institutions in France or abroad, or from public or private research centers.
L'archive ouverte pluridisciplinaire HAL, est destinée au dépôt et à la diffusion de documents scientifiques de niveau recherche, publiés ou non, émanant des établissements d'enseignement et de recherche français ou étrangers, des laboratoires publics ou privés. 


\title{
Stabilization of dichalcogenide ligands in the coordination sphere of ruthenium system
}

\author{
Koushik Saha, ${ }^{a}$ Sourav Gayen, ${ }^{a}$ Urminder Kaur, ${ }^{a}$ Thierry Roisnel, ${ }^{\text {b }}$ and Sundargopal Ghosh*a
}

\begin{abstract}
Synthesis, structure and electronic properties of the tetraruthenium dichalcogenide complexes displaying exclusive coordination mode of dichalcogenide ligands have been discussed. The reaction of $\mathrm{Li}\left[\mathrm{BH}_{2} \mathrm{E}_{3}\right](\mathrm{E}=\mathrm{S}$ or Se) with $[\mathrm{ClRu}(\mu-\mathrm{Cl})(p \text {-cymene })]_{2} \quad\left(p\right.$-cymene $\left.=\eta^{6}-\left\{p-\mathrm{C}_{6} \mathrm{H}_{4}\left({ }^{\prime} \mathrm{Pr}\right) \mathrm{Me}\right\}\right)$ at room temperature yielded tetrametallic dichalcogenide complexes $\left[\left\{\mathrm{Ru}_{2} \mathrm{Cl}_{2}(p \text {-cymene })_{2}\right\}_{2}\left(\mu_{4}, \eta^{2}-\mathrm{E}_{2}\right)\right], \mathbf{1 - 2}(\mathrm{E}=\mathrm{S}(\mathbf{1})$ and $\mathrm{Se}(\mathbf{2}))$. The solid-state X-ray structure of 1 shows that two $\{(p \text {-cymene }) R u C l\}_{2}$ moieties are bridged by a $S-S$ bond. In addition to 2 , the reaction of $\mathrm{Li}\left[\mathrm{BH}_{2} \mathrm{Se}_{3}\right]$ with $[\mathrm{ClRu}(\mu-\mathrm{Cl})(p \text {-cymene })]_{2}$ also yielded a mononuclear tris-homocubane analogue $[\mathrm{Ru}(p$ cymene) $\left.\left\{\mathrm{Se}_{7}(\mathrm{BH})_{3}\right\}\right](3)$ which is an analogue of 1,3,3-tris-homocubane and possesses $D_{3}$ symmetry. In order to isolate the $\mathrm{Cp}^{*}$ analogue of 1 , reaction of $[\mathrm{Cp} * \mathrm{Ru}(\mu-\mathrm{Cl}) \mathrm{Cl}]_{2}$ with $\mathrm{Li}\left[\mathrm{BH}_{2} \mathrm{~S}_{3}\right]$ was carried out that led to the formation of bis/tris-homocubane derivatives [(Cp*Ru $\left.{ }_{2}\left\{\mu-\mathrm{S}_{\mathrm{n}}(\mathrm{BH})_{2}\right\}\right](\mathrm{n}=7(4)$ and $6(5))$ along with the formation of ruthenium disulfide complexes [(RuCp* $\left.)_{2}\left(\mu, \eta^{2}: \eta^{2}-\mathrm{S}_{2}\right)\left(\mu, \eta^{1}: \eta^{1}-\mathrm{S}_{2}\right)\right]$ and [(RuCp* $)_{2}\left(\mu\right.$-SBHS- $\left.\left.\kappa^{1} \mathrm{~B}: \kappa^{2} \mathrm{~S}: \kappa^{2} \mathrm{~S}\right)\left(\mu, \eta^{1}: \eta^{1}-\mathrm{S}_{2}\right)\right]$. Complexes 1-5 have been characterized by multi-nuclear NMR, IR, UV-Vis spectroscopy, mass spectrometry and their molecular formulations (except 2) have been inferred by single crystal X-ray crystallography. Further, the DFT calculations were performed that rationalize the stabilization of the dichalcogenide units $\left(E_{2}{ }^{2-}\right)$ by the tetrametallic systems in 1-2.
\end{abstract}

\section{Introduction}

A continuous interest in developing the transition-metal dichalcogenide complexes is observed due to their use as suitable precursors for generating binary metal chalcogenide quantum dots and thin films. ${ }^{1}$ The transition-metal dichalcogenide complexes are comparatively less explored than the transition metal chalcogenide complexes and the field of dichalcogenide complexes was developed rapidly in the last two decades. ${ }^{2}$ The well-established method to prepare these species is the oxidative transfer of the chalcogen source to metal complexes. For example, complex $\left[\left\{(\mathrm{OC})_{3} \mathrm{Fe}\right\}_{4}\left(\mu-\mathrm{S}_{2}\right)(\mu-\mathrm{SPh})_{2}\right]^{3 \mathrm{a}}$ was isolated via the $\mathrm{SO}_{2} \mathrm{Cl}_{2}$ oxidation of $\left[\left\{(\mathrm{OC})_{3} \mathrm{Fe}\right\}_{2}(\mu-\mathrm{S})(\mu-\mathrm{SPh})\right] \mathrm{Li}(\mathrm{Chart} 1){ }^{3}$ Whereas, thermolysis of the chromium sulfide complex $\left[(\mathrm{CpCr})_{2}\left(\mu-\mathrm{S}^{t} \mathrm{Bu}\right)_{2}(\mu-\mathrm{S})_{2}(\mathrm{NO})_{2}(\mathrm{Cl})_{2}\right]$ led to the formation of $\left[(\mathrm{CpCr})_{4}(\mathrm{NO})_{3}(\mathrm{Cl})\left(\mu-\mathrm{S}^{t} \mathrm{Bu}\right)_{2}\left(\mu-\mathrm{S}_{2}\right)\right]$, ${ }^{3 \mathrm{c}}$. Other transition metal dichalcogenide complexes featuring $\left\{\mathrm{M}_{2} \mathrm{E}-\mathrm{EM}_{2}\right\}$ core, listed in Chart 1 , were also synthesized using different synthetic strategies. ${ }^{3}$ It was observed that the ancillary ligand/s (such as $\mathrm{Cp}, \mathrm{Cp}$ * etc.) stabilize the metal-dichalcogenide complexes. Thus, the metal centers bearing ancillary ligands have been used to stabilize the dichalcogenide complexes. On the other hand, it becomes apparent that the sterically bulky and electronegative ancillary ligands, such as $\mathrm{Cp}^{*}$, are not mandatory to stabilize the lanthanide chalcogenide complexes having $\mathrm{Ln}-\mathrm{E}$ bonds. ${ }^{4}$ Therefore, inspection on the reactivity of other ancillary ligand/s (such as $p$-cymene, $\operatorname{cod}\left(\eta^{4}-\mathrm{C}_{4} \mathrm{H}_{8}\right)$, etc.) containing transition metal complexes become of particular interest to synthesize transition metal dichalcogenides. A detailed investigation would be advantageous to comprehend the prerequisite conditions desired to stabilize the dichalcogenide ligands in the coordination sphere of the transition metal centers.

In an attempt to isolate the chalcogen-rich transition metal species, the reactivity of chalcogenated ligands $\mathrm{Li}\left[\mathrm{BH}_{2} \mathrm{E}_{3}\right]^{5}\left(\mathrm{E}=\mathrm{S}\right.$, Se and Te), were investigated. ${ }^{6}$ In our earlier report, we have effectively substantiated the utility of $\mathrm{Li}\left[\mathrm{BH}_{2} \mathrm{E}_{3}\right]\left(\mathrm{E}=\mathrm{S}\right.$ or Se) to isolate metal chalcogenide complexes of molybdenum, $\left[(\mathrm{OC})_{2} \mathrm{MoCp} *\left(\eta^{2}-\mathrm{SC}(\mathrm{Me}) \mathrm{S}\right)\right]$ and $\left[(\mathrm{OC})_{2} \mathrm{MoCp}^{*}\left(\eta^{1}-\mathrm{SeEt}\right)\right]^{6 \mathrm{6a}}$ Further, the reaction of $\left[\mathrm{Cp}^{*} \mathrm{MCl}_{4}\right]\left(\mathrm{M}=\mathrm{Nb}\right.$ and Ta) with $\mathrm{Li}\left[\mathrm{BH}_{2} \mathrm{E}_{3}\right](\mathrm{E}=\mathrm{S}$, Se, or Te) yielded various metal chalcogenide complexes along with chalcogen rich trimetallic cubane type complexes. ${ }^{7}$ Therefore over the years, the interest have grown to investigate the reactivity of $\mathrm{Li}\left[\mathrm{BH}_{2} \mathrm{E}_{3}\right]$ with heavier metal precursors. ${ }^{8}$ To investigate the effect of the ancillary ligand as well as chalcogenide ligand on the stability of metal-chalcogenide complexes of ruthenium, we chose $[(p \text {-cymene }) \operatorname{Ru}(\mu-\mathrm{Cl}) \mathrm{Cl}]_{2}$ as a suitable metal precursor. Herein, we have studied the syntheses and structural characterizations of dichalcogenide complexes and bis/tris-homocubane analogues of ruthenium. 


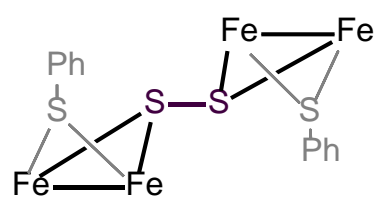

2.108(3) ^

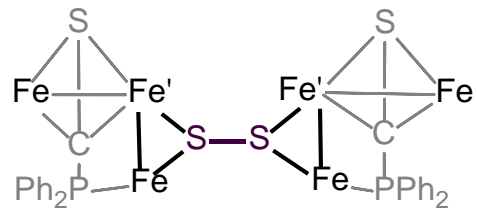

$2.1490(9) \AA$

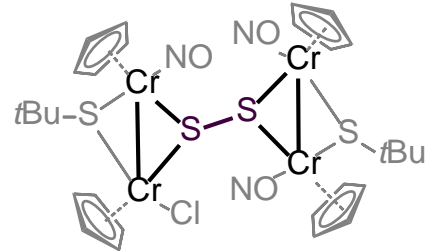

$2.107(3) \AA$

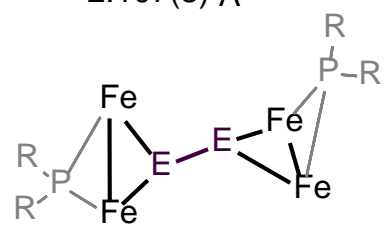

$\mathrm{E}=\mathrm{S}, \mathrm{R}=\mathrm{O}^{i} \mathrm{Pr} ; 2.1222(8) \AA$

$\mathrm{E}=\mathrm{Se}, \mathrm{R}={ }^{i} \mathrm{Pr} ; 2.4220(4) \AA$

$\mathrm{E}=\mathrm{Te}, \mathrm{R}={ }^{i} \mathrm{Pr} ; 2.8319(14) \AA$

Chart 1. Selected examples of transition metal dichalcogenide complexes featuring an $E-E$ bond $(E=S$, Se or Te). All the bond distances mentioned are the E-E bond distances.

\section{Results and Discussion}

\section{Synthesis of tetrametallic dichalcogenide complexes, $\left[\left\{\mathrm{Ru}_{2} \mathrm{Cl}_{2}(p \text {-cymene })_{2}\right\}_{2}\left(\mu_{4}, \eta^{2}-\mathrm{E}_{2}\right)\right](\mathrm{E}=\mathrm{S}$ or Se$)$}

After the isolation of metal-chalcogenide complexes of early transition metals using $\mathrm{Li}\left[\mathrm{BH}_{2} \mathrm{E}_{3}\right](\mathrm{E}=\mathrm{S}$ or Se) ligand, we applied the same approach with late transition metals. As a result, the room temperature reaction of [ClRu(pcymene) $(\mu-\mathrm{Cl})]_{2}$ with $\mathrm{Li}_{[}\left[\mathrm{BH}_{2} \mathrm{~S}_{3}\right]$ was performed. The color of the reaction mixture turned brown from red during the progress of the reaction. After the chromatographic separation, a red solid, $\left[\left\{\mathrm{Ru}_{2} \mathrm{Cl}_{2}(p \text {-cymene })_{2}\right\}_{2}\left(\mu_{4}, \eta^{2}-\mathrm{S}_{2}\right)\right] \mathbf{1}$ was obtained in $6 \%$ yield. Note that, some air and moisture sensitive compounds were also formed in this reaction which could not be isolated due to the lower yields and unstable nature. Due to complexity of the reaction, presently we don't have clear idea about the main product/s and we were only able to isolate complex 1. In case of selenium, the reaction of $[\mathrm{ClRu}(\mu-\mathrm{Cl})(p \text {-cymene })]_{2}$ and $\mathrm{Li}\left[\mathrm{BH}_{2} \mathrm{Se}_{3}\right]$ under similar reaction conditions permitted us to isolate red $\left[\left\{\mathrm{Ru}_{2} \mathrm{Cl}_{2}(p \text {-cymene })_{2}\right\}_{2}\left(\mu_{4}, \eta^{2}-\mathrm{Se}_{2}\right)\right], 2$ and orange $\left[\mathrm{Ru}(p\right.$-cymene $\left.)\left\{\mathrm{Se}_{7}(\mathrm{BH})_{3}\right\}\right], \mathbf{3}$ in 5 and $38 \%$ yields respectively (Scheme 1). The reaction of $[\mathrm{ClRu}(p \text {-cymene })(\mu-\mathrm{Cl})]_{2}$ and $\mathrm{Li}_{2}\left[\mathrm{BH}_{2} \mathrm{Te}_{3}\right]$ led to decomposition of the starting materials. The ${ }^{1} \mathrm{H}$ and ${ }^{13} \mathrm{C}\left\{{ }^{1} \mathrm{H}\right\}$ NMR chemical shifts confirmed the presence of $p$-cymene units in $\mathbf{1}$ and $\mathbf{2}$.

The solid-state structure of 1 revealed the identity as a tetraruthenium disulfide complex where a disulfide unit bridges two $\{(p \text {-cymene }) \mathrm{Ru}(\mathrm{Cl})\}_{2}$ moieties (Fig. 1). Complex 1 resides in a general position in the monoclinic space group $P 2_{1} / c$ as similar to that in $\left[\left\{\mathrm{Fe}_{2}(\mathrm{CO})_{6}\left(\mu_{4}-\mathrm{E}\right) \operatorname{Re}_{2}(\mathrm{CO})_{8}\left(\mu-\mathrm{PC} y_{2}\right)\right\}_{2}\left(\mu_{4}, \eta^{2}-\mathrm{S}_{2}\right)\right]^{9}$ and the two asymmetric moieties i.e. $\{(p \text {-cymene }) \mathrm{Ru}(\mathrm{Cl})\}_{2} \mathrm{~S}$ are arranged in a triangular geometry. All the Ru atoms in $\mathbf{1}$ are in a distorted octahedral environment. Two $\{(p$-cymene $) \mathrm{Ru}(\mathrm{Cl})\}$ fragments in $\mathbf{1}$ are held together through a Ru-Ru single bond (2.959(2) $\AA$ ). The metal-metal bond distance in 1 is similar to that of arachno- $\left[\left(\mathrm{Cp}^{*} \mathrm{Ru}\right)_{2} \mathrm{~B}_{3} \mathrm{H}_{8}\left(\mathrm{CS}_{2} \mathrm{H}\right)\right]^{10}(2.9738(3) \AA)$ but longer compared to the bridging boryl borylene complex of ruthenium $\left[\left(\mu-\mathrm{SCH}_{2} \mathrm{SHB}-\kappa^{2} B: \kappa^{2} S\right)\left(\mathrm{RuCp}{ }^{*}\right)_{2}\left\{\mu-\mathrm{C}(\mathrm{Me})\left(\mathrm{C}_{6} \mathrm{H}_{4}\right) \mathrm{B}-\right.\right.$ $\left.\left.\kappa^{2} B: K^{2} C\right\}\right]^{11}(2.4608(10) \AA)$. The $\left\{\mathrm{Ru}_{2} \mathrm{SCl}\right\}$ units in 1 are planar and similar to the $\left\{\mathrm{Cr}_{2} \mathrm{~S}_{2} \mathrm{Cl}\right\}$ unit in $\left[\mathrm{Cl}(\mathrm{CpCr})_{4}(\mathrm{NO})_{3}(\mu-\right.$ $\left.\left.\mathrm{S}^{t} \mathrm{Bu}\right)_{2}\left(\mu_{4}, \eta^{2}-\mathrm{S}_{2}\right)\right]^{3 \mathrm{c}}$. Complex 1 contains two planar $\left\{\mathrm{Ru}_{2} \mathrm{~S}\right\}$ units, which are linked by a disulfide bond and with a dihedral angle of $16.83^{\circ}$ between the two $\left\{\mathrm{Ru}_{2} \mathrm{~S}\right\}$ planes. The bridging disulfide ligand in $\mathbf{1}$ is neither vertical (as that in $\left.\left.\left[\mathrm{Fe}_{3}(\mathrm{CO})_{8}\left(\mathrm{Ph}_{2} \mathrm{PCS}\right)\right\}_{2}\left(\mu_{4}, \eta^{2}-\mathrm{S}_{2}\right)\right]^{3 b}\right)$ nor parallel as in case of $\left.\left[\left\{(\mathrm{OC})_{6} \mathrm{Fe}_{2}(\mu-\mathrm{SEt})\right\}_{2}\left(\mu_{4}, \eta^{2}-\mathrm{S}_{2}\right)\right]^{12}\right)$ to the perpendicular axes

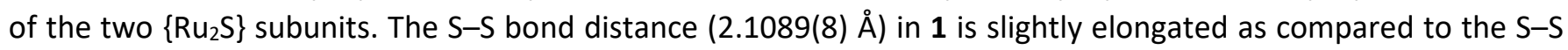
bonds in $\mathrm{S}_{8}$ molecule $(2.037(5) \AA)$. However, the $\mathrm{S}-\mathrm{S}$ bond distance in $\mathbf{1}$ is comparable to $\left[\left\{\mathrm{Fe}_{2}(\mathrm{CO})_{6}\left(\mu-\mathrm{SC}_{6} \mathrm{H}_{5}\right)\right\}_{2}\left(\mu_{4}, \eta^{2}-\right.\right.$ $\left.\left.\mathrm{S}_{2}\right)\right]^{3 a}(2.106(3) \AA)$ and slightly shorter than $\left[\left\{\mathrm{Fe}_{2}(\mathrm{CO})_{6}(\mu-\mathrm{S})\right\}_{2}\left(\mu_{4}, \eta^{2}-\mathrm{S}_{2}\right)\right]\left[\mathrm{K}(\text { benzo-15-crown-5 })_{2}\right]_{2}{ }^{3 f}(2.1657(17) \AA ̊)$. Two acute $\angle \mathrm{Ru}$-S-Ru angles $\left(78.30(2)\right.$ and $\left.78.52(2)^{\circ}\right)$ confirm that the $\mathrm{S}_{2}{ }^{2-}$ ligand are positioned with respect to the metal centers in almost orthogonal direction. The ruthenium-sulfur bond lengths in $\mathbf{1}$ (avg. $2.325 \AA$ ) fall in the region of 
single bond lengths and comparable with that in $\left[(\mathrm{Cp} * \mathrm{Ru})_{2}\left(\mu, \eta^{3}-\mathrm{CHS}\right)_{2}\right]^{13 a}(2.3733 \AA)$ and $\left[\{\mathrm{Ru}(p \text {-cymene })\}_{2} \mathrm{Ru}\right.$ $\left.\left(\mu_{3}, \eta^{2}: \eta^{2}-\mathrm{S}_{2}\right)\left(\mu, \eta^{1}: \eta^{1}-\mathrm{S}_{2}\right)\left(\mu-\mathrm{S}_{2} \mathrm{C}_{2} \mathrm{~B}_{10} \mathrm{H}_{10}\right)_{2}\right]^{13 \mathrm{~b}}(2.3733 \AA)$.

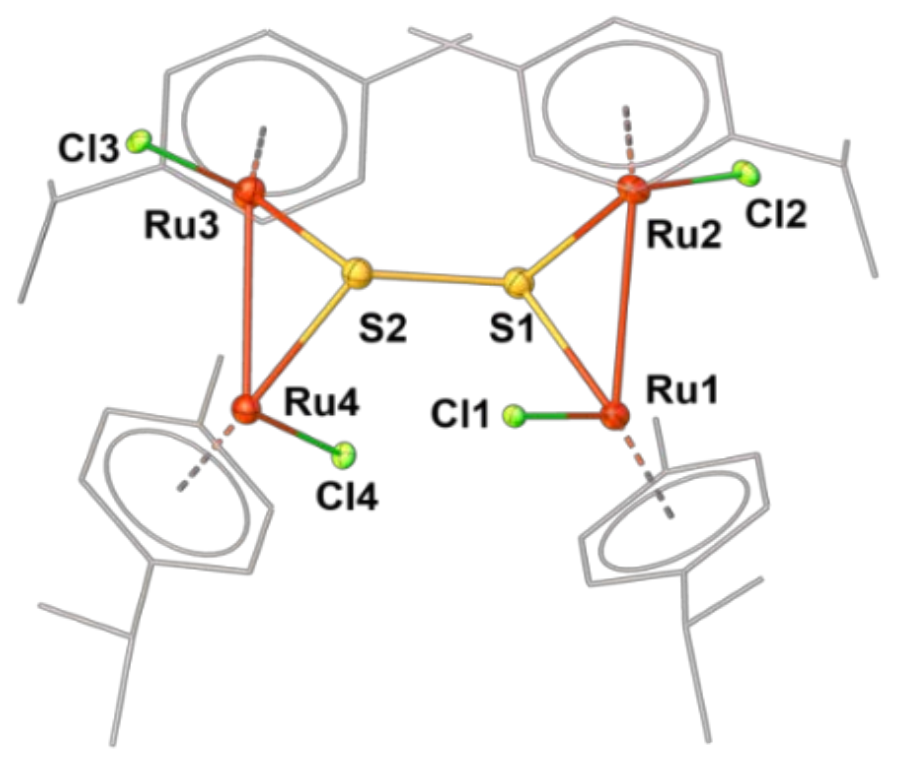

Fig. 1 Molecular structure of 1. Selected bond lengths $(\AA ̊)$ and angles $\left({ }^{\circ}\right)$ are: S1-S2 2.1089(8), Ru1-Ru2 2.9392(3), Ru3-Ru4 2.9395(4), Ru1-S1 2.3202(6), Ru2-S1 2.3350(6), Ru3-S2 2.3298(6), Ru4-S2 2.3150(6); Ru1-S1-Ru2 78.30(2), Ru4-S2-Ru3 78.52(2), S1-S2-Ru3 110.03(3), S1-S2-Ru4 115.03(3).

Interestingly, similar types of metal complexes with E-E bond are known in the literature, and some of them are listed in Table 1. ${ }^{3 a, 38,3 h, 12,14}$ Having a good number of complexes, similar to that of $\mathbf{1}$, allowed us to compare the structural parameters of 1 with relevant species. As shown in Table 1, the E-E bond distances are within the range

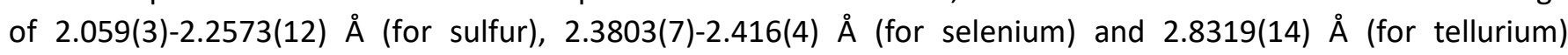
corresponding to the single $\mathrm{E}-\mathrm{E}$ bond distance. It is interesting to note that, in $\left[\left\{\mathrm{Fe}_{2} \mathrm{Se}(\mathrm{CO})_{6}\right\}_{2}-\left(\mu_{4}, \eta^{2}-\mathrm{Se}_{2}\right)\left(\mathrm{PPh}_{4}\right)_{2}\right]^{14 a}$, the Se-Se separation of $2.847(5) \AA$ is merely an interaction rather than a single bond. As a result, the E-E distance of these species provide a preliminary indication of the true nature of the E-E interaction. As presented in Table 1, it is apparent that the substitution at metal center directly affects the E-E bond distance that generally depends on the electronic nature of the substituents associated with the metal center. On the other hand, the M-M bond distance of these complexes directly depends both on the substituents at metal centers and strength of the chelation between dichalcogenide unit/s and metal centers. Limited availability of the examples of $M_{4} E_{2}$ complexes containing an E-E bond made complexes 1, 2 a prominent entry in the metal dichalcogenide complexes.
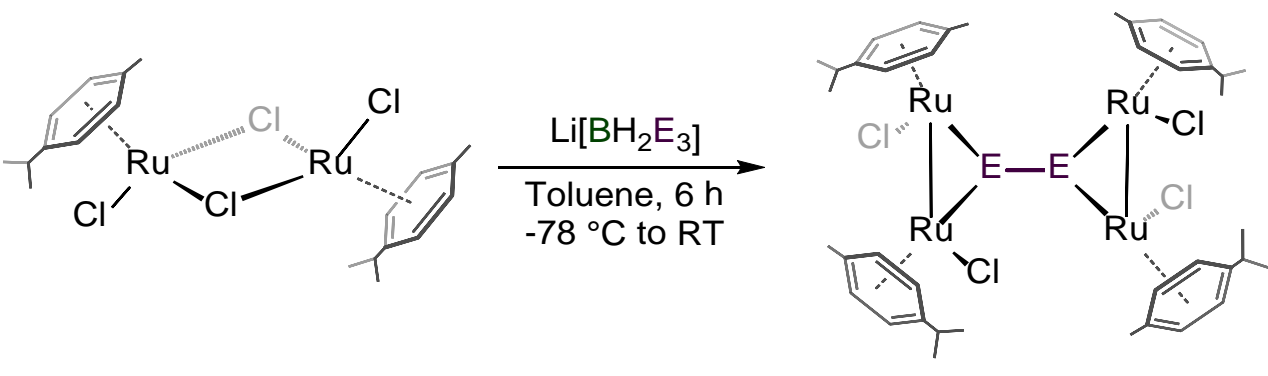

$$
\mathrm{E}=\mathrm{S}(\mathbf{1}) ; \mathrm{Se}(\mathbf{2})
$$

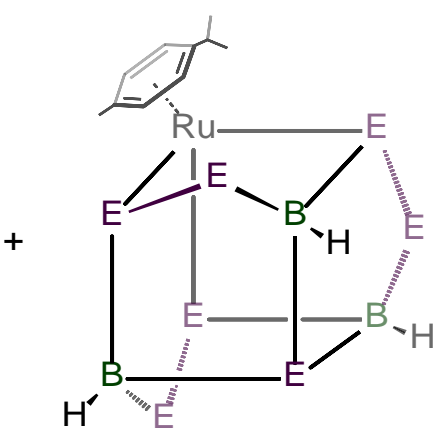

$E=\operatorname{Se}(\mathbf{3})$

Scheme 1 Synthesis of tetranuclear dichalcogenide complexes of ruthenium. 


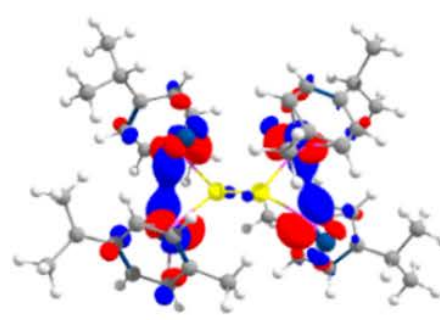

(a)

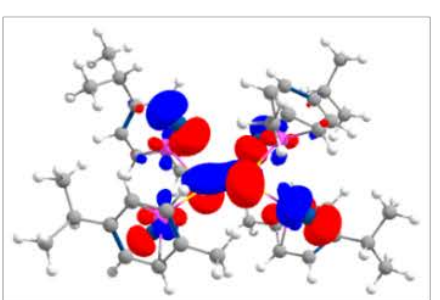

(b)

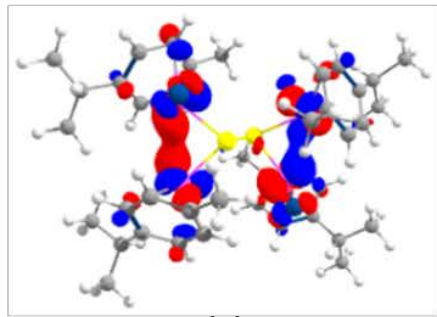

(c)

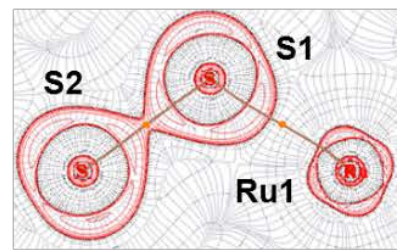

(d)

Fig. 2 (a) HOMO, (b) HOMO-13 and (c) LUMO of 1. (d) Contour line diagram of Laplacian of electron density of 1 along the Ru-S1-S2 plane. Solid red lines specify areas of charge concentration $\left(\nabla^{2} \rho(r)<0\right)$ and dashed black lines display areas of charge depletion $\left(\left(\nabla^{2} \rho(r)>0\right)\right.$. Orange dots show bond critical points and solid brown lines display bond paths.

Although, many examples of the tetrametallic complexes featuring an E-E bond are known, lack of theoretical investigations casted uncertainty on the bonding of these complexes. Therefore, the density functional theory (DFT) calculations were carried out to analyze the electronic structures of the tetrametallic dichalcogenide complexes $\mathbf{1}$, 2 and 2' (Te analogue of $\mathbf{1}$ ) using B3LYP functional and SDD/6-31G basis set. The symmetrical X-ray structure of 1 has slightly been distorted after the optimization and as a result, the Ru3-Ru4 bond distance was lengthened to 3.074 ̊̊. However, the Ru1-Ru2 bond distance remained almost same (2.940 ̊̊). Although, a bond critical point between the Ru-Ru bond is not observed, the HOMO and LUMO of the complexes 1, $\mathbf{2}$ and 2' showed bonding interactions between the ruthenium atoms of the $\left\{(p \text {-cymene })_{2} \mathrm{Ru}_{2}(\mathrm{Cl})_{2} \mathrm{E}\right\}$ units (Figs. $2 \mathrm{a}, 2 \mathrm{c}$ and S16). The NBO calculations revealed the WBI (Wiberg bond indices) values in the range of 0.413-0.293 for these Ru-Ru bonds which is typical for the formal single bonds between transition metals $(0.2-0.3)^{15}$ and similar to that diruthenium complexes $\left[\left(\mathrm{RuCp}^{*}\right)_{2}\left\{\mu-\mathrm{C}(\mathrm{Me}) \mathrm{C}_{6} \mathrm{H}_{4} \mathrm{~B}-\kappa^{2} \mathrm{C}: \kappa^{2} \mathrm{~B}\right\}\left(\mu-\mathrm{HBCH}_{2} \mathrm{~S}_{2}-\kappa^{2} \mathrm{~S}: \kappa^{2} \mathrm{~B}\right)\right]^{11}(0.3753)$ and $\left[\left(\mathrm{Cp}^{*}-\mathrm{Ru}\right)_{2}\left(\mu, \eta^{2}-\mathrm{C}_{2}{ }^{t} \mathrm{Bu}_{2}\right)\left(\mu, \eta^{2}-\mathrm{P}_{2}\right)\right]^{16}$ (0.26). Based on the bond distances and WBI values of Ru-Ru separation, we believe the presence of a Ru-Ru single bond in 1, $\mathbf{2}$ and $\mathbf{2}^{\prime}$. The MO analyses of these complexes suggest that the HOMO-LUMO gaps follow the order of 1 $<\mathbf{2}<\mathbf{2}^{\prime}\left(0.073(\mathbf{1}), 0.072(\mathbf{2})\right.$ and $0.069 \mathrm{eV}\left(\mathbf{2}^{\prime}\right)$, Fig. S16) and are considerably smaller as compared to the reported disulfide species $\left[(\mathrm{Cp} * \mathrm{Ru})_{2}\left(\mu, \eta^{2}: \eta^{2}-\mathrm{S}_{2}\right)\left(\mu, \eta^{1}: \eta^{1}-\mathrm{S}_{2}\right)\right]^{11}(3.115 \mathrm{eV})$.

The HOMO-13 of 1, $\mathbf{2}$ and 2' showed the overlap between the $p$ orbitals of the corresponding chalcogen atoms (Figs. $2 \mathrm{~b}$ and S17) that indirectly verifies the presence of a strong $\mathrm{E}-\mathrm{E}$ single bond. Further, the NBO analysis also indicate a strong $\mathrm{E}-\mathrm{E}$ bonding interaction that indirectly verifies the presence of a strong E-E bond (Fig. S18). The topological analyses for 1 revealed the existence of bond critical point (BCP) between S1 and S2 $(\rho(0.110 \mathrm{amu})$, $\nabla^{2} \rho(-0.042 \mathrm{amu})$ ) atoms (Fig. 2d). A decreasing trend is observed in the WBI values of the E-E bonds for 1, 2 and 2' (1: $0.8096,2: 0.7832$ and 2': 0.7476). In addition, a series of strong bonding interactions between the Ru and $E$ atoms have been observed that indirectly demonstrate the stabilization of the dichalcogenide ligands by the tetrametallic system (Fig. S18). The DFT calculations also elaborate the fact that the dichalcogenide ligand acts as a dianionic $E_{2}{ }^{2-}$ species instead of neutral $E_{2}$. As shown in Tables $S 2$ and $S 3$, a charge transfer from chalcogen centre to ruthenium centre has been observed. Thus, chalcogen atoms in 1-2' possess positive natural charges and Ru atoms possess negative natural charges. Thus, one would expect a positive increase in the value of natural charges on the chalcogen atoms of 1-2' as compared to the free $E_{2}$ ligand. As a result, we have compared the natural charges on the sulfur atoms in $1\left(q_{\mathrm{E}}=0.290\right)$, free neutral disulfur $\left(\mathrm{S}_{2}\right)\left(q_{\mathrm{E}}=0.00\right)$ and the dianionic disulfide $\left(\mathrm{S}_{2}{ }^{2-}\right)\left(q_{\mathrm{E}}=-1.00\right)$ species. We have observed that the positive increase of natural charges on sulfur atoms is more prominent from $\mathrm{S}_{2}{ }^{2-}$ to 1 as compared to $\mathrm{S}_{2}$ to $\mathbf{1}$. A similar observation has also been found in case of $\mathbf{2}$ and $\mathbf{2}^{\prime}$ (Table $\mathrm{S} 2$ ). The electron donation from the dichalcogenide ligand to the metal centre has also been supported by the decrease of natural valance population of the $E$ atom $\left(\mathrm{p}_{\mathrm{E}}\right)$ and increase in Ru atom simultaneously (Table S2). The extent of ligand to metal charge transfer follows a gradually increasing trend from 1-2' (Table S3). The WBI values of the E-E bonds for 1, 2 and 2' (1: 0.8096, 2: 0.7832 and 2': 0.7476) are closer to free $E_{2}{ }^{2-}$ than neutral $E_{2}$ species and follows a decreasing trend of $\mathbf{1}>\mathbf{2}>\mathbf{2}$ ' (Table S2). This fact indirectly suggests the presence of an E-E single bond. We believe this could 
be one of the main reasons for not able to isolate complex $2^{\prime}$ from the reaction of $[\mathrm{ClRu}(p \text {-cymene })(\mu-\mathrm{Cl})]_{2}$ and $\mathrm{Li}\left[\mathrm{BH}_{2} \mathrm{Te}_{3}\right]$. The detailed theoretical investigation on 1-2' shed light on the true nature of the $\mathrm{E}-\mathrm{E}$ bond.

In order to know the nature of $\mathrm{Ru}_{2} \mathrm{~S}$ triangular ring in 1 , the investigation of aromaticity has been carried out by nucleus independent chemical shift (NICS) method. The $\mathrm{Ru}_{2} \mathrm{~S}$ ring in 1 showed negative NICS values both for NICS(0) and NICS(1). The NICS(0) value is -58.22 which is quite higher as compared to the aromatic cyclic hydrocarbons. On the other hand, the NICS(1) value of -18.824 . Thus, the $\mathrm{Ru}_{2} \mathrm{~S}$ ring shows both the $\sigma$ - and $\pi$-aromaticity.

\section{Tris-homocubane analogue, 3}

Along with the formation of $\mathbf{2}$, compound $\mathbf{3}$ was also isolated as an orange solid in $\mathbf{3 8 \%}$ yield. This compound is characterized by multinuclear spectroscopy and single crystal X-ray crystallography. The ${ }^{11} \mathrm{~B}\left\{{ }^{1} \mathrm{H}\right\}$ chemical shift that appeared at the downfield region $(\delta-7.2 \mathrm{ppm})$ indicate the presence of tetracoordinated boron atom. The ${ }^{1} \mathrm{H}$ NMR spectrum displayed a septet at $\delta 2.04 \mathrm{ppm}$ for the methine proton of the $p$-cymene unit suggesting the possibility of one chemically distinct metal environment. The signal at $\delta 4.28 \mathrm{ppm}$ is attributed to the $\mathrm{BH} t$ protons. The molecular ion $\left[\mathrm{M}+\mathrm{CH}_{3} \mathrm{CN}\right]^{+}$peak at $\mathrm{m} / 2864.6$ corresponds to the molecular formula of $\mathrm{C}_{12} \mathrm{H}_{20} \mathrm{~B}_{3} \mathrm{RuNSe}_{7}$. This indicates that the three boron atoms may reside in similar positions and the molecule possesses a symmetry.

Further, the X-ray diffraction analysis was performed on a single crystal to elucidate the structure of $\mathbf{3}$. The solidstate $\mathrm{X}$-ray structure of $\mathbf{3}$ revealed a monometallic tris-homocubane alike core formulated as $[\mathrm{Ru}(p$ cymene) $\left.\left\{\mathrm{Se}_{7}(\mathrm{BH})_{3}\right\}\right]$ (Fig. 3). Compound $\mathbf{3}$ is isostructural and isoelectronic with another tris-homocubane analogue $\left[\mathrm{Cp} * \mathrm{Co}\left\{\mathrm{Se}_{7}(\mathrm{BH})_{3}\right\}\right]^{17}$. Three selenium atoms in $\mathbf{3}$ are bridged between the edge-shared boron and selenium atoms of the tris-homocubane core. As a result, the bond separations between the boron and selenium are elongated (for e.g., B1 and Se5). All the boron atoms in $\mathbf{3}$ are in symmetrical tetrahedral environment and surrounded by three Se and one $\mathrm{H}$ atom/s. The average $\mathrm{B}-\mathrm{Se}$ bond length in $3(2.043 \AA)$ is notably longer as compared to that of $\left[(\mathrm{Cp} * \mathrm{Mo})_{2} \mathrm{~B}_{4} \mathrm{Se}_{2} \mathrm{H}_{4}\right]^{18}(1.923 \AA)$. The average $\angle \mathrm{Se}-\mathrm{B}-\mathrm{Se}$ in $\mathbf{3}\left(108.3^{\circ}\right)$ is slightly shorter than the tetrahedral angle $\left(109.3^{\circ}\right)$ with a maximum deviation of $3.6^{\circ}$. This confirms the tetrahedral nature of the boron atoms. On the other hand, the average $\mathrm{B}-\mathrm{E}$ and $\mathrm{E}-\mathrm{E}$ bond distances are in the range of corresponding single bond distance. Compound 3 can be considered as a tris-homocubane analogue of the pentacyclo-[6.3.0.02,6.03, 10.05.9]-undecane and possesses $D_{3}$ symmetry. Note that, the known example of smallest rigid organic compound having $D_{3}$ symmetry is the $D_{3}$-tris-homocubane. On the other hand, compound $\mathbf{3}$ having a $p$-cymene unit as an ancillary ligand is prone to the arene displacement due to the labile nature of the $\eta^{6}$-coordinated ligand and susceptible towards the ligand displacement reactions. ${ }^{19}$

The cubanes and their derivatives are electron-precise molecules and generally they obey cluster valence electron (cve) count. The cve count for tris-homocubane $\mathrm{C}_{11} \mathrm{H}_{14}$ consisting of eight $\mathrm{CH}$ vertices and three $\mathrm{CH}_{2}$ bridges is 58 $\left[8(\mathrm{CH}) \times 5+3\left(\mathrm{CH}_{2}\right) \times 6=58\right]$. Therefore, the tris-homocubane analogue comprising one transition metal should have the electron count of 68 . Indeed, compound 3 has 68 cve $[1\{(p$-cymene $) R u\} \times 14+7(\mathrm{Se}) \times 6+3(\mathrm{BH}) \times 4=68]$.

\section{Syntheses of diruthenium bis/tris-homocubane analogues, $\left[(\mathrm{Cp} * \mathrm{Ru})_{2}\left\{\mu-\mathrm{S}_{\mathrm{n}}(\mathrm{BH})_{2}\right\}\right](\mathrm{n}=7$ and 6$)$}

Recently, we have reported the synthesis of ruthenium disulfide $\left[(\operatorname{RuCp} *)_{2}\left(\mu, \eta^{2}: \eta^{2}-S_{2}\right)\left(\mu, \eta^{1}: \eta^{1}-S_{2}\right)\right]$ and diruthenium boryl [(RuCp* $)_{2}\left(\mu\right.$-SBHS- $\left.\left.\kappa^{1} \mathrm{~B}: \kappa^{2} \mathrm{~S}: \kappa^{2} \mathrm{~S}\right)\left(\mu, \eta^{1}: \eta^{1}-\mathrm{S}_{2}\right)\right]$ species from the reaction of [Cp*Ru( $\mu$-Cl)Cl] $]_{2}$ with Li[B $\left[\mathrm{BH}_{2} \mathrm{~S}_{3}\right]$. In a stark contrast, the reaction of $\left[\mathrm{ClRu}(\mu \text {-Cl) }(p \text {-cymene })]_{2}\right.$ with $\mathrm{Li}\left[\mathrm{BH}_{2} \mathrm{~S}_{3}\right]$ yielded tetrametallic disulfide complex 1 . As a result, we reexamined the chemistry of $\mathrm{Cp}{ }^{*}$ Ru-based systems and performed the reaction of $[\mathrm{Cp} * \mathrm{Ru}(\mu-\mathrm{Cl}) \mathrm{Cl}]_{2}$ with $\mathrm{Li}\left[\mathrm{BH}_{2} \mathrm{~S}_{3}\right]$ under various reaction conditions. Although we did not able to isolate the $\mathrm{Cp}^{*}$ analogue of 1, i.e. $\left[(\mathrm{Cp} * \mathrm{Ru})_{2} \mathrm{Cl}_{2}\right]_{2}\left(\mu_{4}, \eta^{2}-\mathrm{E}_{2}\right)$, the reaction yielded two inseparable ruthenium bis/tris-homocubane analogues, $\left[(\mathrm{Cp} * \mathrm{Ru})_{2}\left\{\mu-\mathrm{S}_{\mathrm{n}}(\mathrm{BH})_{2}\right\}\right](\mathrm{n}=7(4)$ and $6(5))$ with an $21 \%$ combined yield along with [(RuCp* $\left.)_{2}\left(\mu, \eta^{2}: \eta^{2}-\mathrm{S}_{2}\right)\left(\mu, \eta^{1}: \eta^{1}-\mathrm{S}_{2}\right)\right]$ and $\left[\left(\mathrm{RuCp}^{*}\right)_{2}\left(\mu\right.\right.$-SBHS- $\left.\left.\kappa^{1} \mathrm{~B}: \kappa^{2} \mathrm{~S}: \kappa^{2} \mathrm{~S}\right)\left(\mu, \eta^{1}: \eta^{1}-\mathrm{S}_{2}\right)\right]$ (Scheme 2$)$. These compounds were characterized by multinuclear spectroscopy and single crystal $\mathrm{X}$-ray crystallography. The ${ }^{1} \mathrm{H}$ chemical shifts at $\delta 1.94$ and $1.78 \mathrm{ppm}$ for $\mathbf{4}$ and $\mathbf{5}$, respectively indicated the presence of two $\mathrm{Cp} *$ units and this was further confirmed by the ${ }^{13} \mathrm{C}\left\{{ }^{1} \mathrm{H}\right\}$ NMR spectrum.

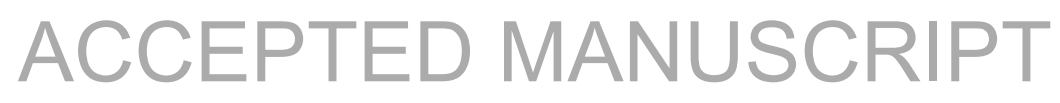


Similarly, the presence of three boron environments at $\delta-5.4,-12.2$ and -12.7 ppm were observed in the ${ }^{11} \mathrm{~B}\left\{{ }^{1} \mathrm{H}\right\}$ NMR spectrum. The mass spectra of them revealed molecular ion peaks at $m / z 743.8735\left([\mathrm{M}+\mathrm{Na}]^{+}\right)$and 719.9303 $\left(\left[\mathrm{M}+\mathrm{CH}_{3} \mathrm{OH}\right]^{+}\right)$corresponding to the molecular formulae $\mathrm{C}_{20} \mathrm{H}_{23} \mathrm{~B}_{2} \mathrm{~S}_{7} \mathrm{Ru}_{2} \mathrm{Na}$ and $\mathrm{C}_{21} \mathrm{H}_{36} \mathrm{~B}_{2} \mathrm{OS}_{6} \mathrm{Ru}_{2}$. The spectrometric and spectroscopic data were not adequate enough to predict the structures of $\mathbf{4}$ and $\mathbf{5}$. Therefore, $\mathrm{X}$-ray quality crystals were grown from the solution of hexane $/ \mathrm{CH}_{2} \mathrm{Cl}_{2}$ (70:30).

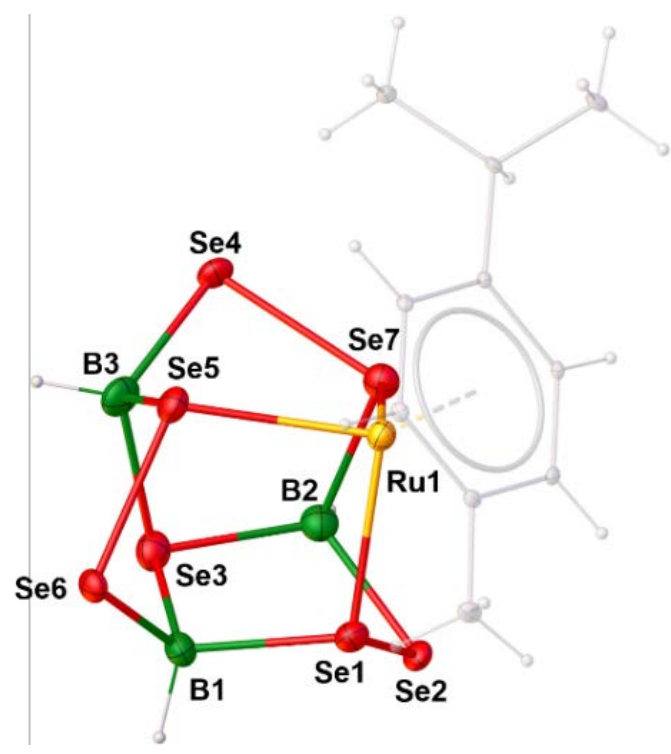

Fig. 3 Molecular structure of 3. Selected bond lengths $(\AA ̊)$ and angles $\left({ }^{\circ}\right)$ : Ru1-Se1 2.4730(10), Ru1-Se5 2.4767(10), Ru1-Se7 2.4787(11), Se1-Se2 2.3628(12), Se4-Se7 2.3600(12), Se5-Se6 2.3542(12), Se1-B1 2.076(8), Se3-B1 2.065(8), Se6-B1 2.020(8), Se2-B2 2.013(8), Se3-B2 2.065(8), Se7-B2 2.073(8), Se3-B3 2.054(9), Se4-B3 2.014(9), Se5-B3 2.099(8); B2-Se2-Se1 89.6(2), B3-Se4-Se7 90.2(2), B1-Se6-Se5 90.4(2).

Table 1. Structural parameters of transition metal dichalcogenide complexes containing $\left\{M_{2} E-E M_{2}\right\}$ core.

\begin{tabular}{|c|c|c|c|c|}
\hline Dichalcogenide complexes & $d(\mathrm{E}-\mathrm{E})^{\mathrm{a}}$ & $d(\mathrm{M}-\mathrm{M})^{\mathrm{a}}$ & $\angle \mathrm{M}-\mathrm{E}-\mathrm{M}^{\mathrm{b}}$ & Ref. \\
\hline$\left[\left\{\mathrm{Fe}_{2}(\mathrm{CO})_{6}(\mu-\mathrm{SEt})\right\}_{2}\left(\mu_{4}, \eta^{2}-\mathrm{S}_{2}\right)\right]$ & $2.113(2)$ & $2.5183(15)$ & $68.32(5)$ & 12 \\
\hline$\left[\left\{\mathrm{Fe}_{2}(\mathrm{CO})_{6}(\mu-\mathrm{SPh})\right\}_{2}\left(\mu_{4}, \eta^{2}-\mathrm{S}_{2}\right)\right]$ & $2.108(3)$ & $2.525(2)$ & 67.8 & $3 a$ \\
\hline$\left[\left\{\mathrm{Fe}_{2}(\mathrm{CO})_{6}\left(\mu-\mathrm{P}^{i} \mathrm{Pr}_{2}\right)\right\}_{2}\left(\mu_{4}, \eta^{2}-\mathrm{Se}_{2}\right)\right]$ & $2.4220(4)$ & $2.5880(4)$ & $66.174(12)$ & $3 \mathrm{~h}$ \\
\hline$\left[\left\{\mathrm{Fe}_{2}(\mathrm{CO})_{6}\left(\mu-\mathrm{P}^{i} \mathrm{Pr}_{2}\right)\right\}_{2}\left(\mu_{4}, \eta^{2}-\mathrm{Te}_{2}\right)\right]$ & $2.8319(14)$ & $2.624(2)$ & $61.65(5)$ & $3 \mathrm{~h}$ \\
\hline $\begin{array}{l}{\left[\left\{\mathrm{Fe}_{2}(\mathrm{CO})_{6}(\mu-\mathrm{Se})\right\}_{2}\left(\mu_{4}, \eta^{2}-\right.\right.} \\
\left.\left.\mathrm{Se}_{2}\right)\left(\mathrm{Ph}_{4} \mathrm{P}\right)_{2}\right]\end{array}$ & $2.847(5)$ & $2.555(6)$ & $65.7(2)$ & $14 a$ \\
\hline$\left[\left\{\mathrm{Fe}_{2}(\mathrm{CO})_{6}\left(\mu-\mathrm{PPh}_{2}\right)\right\}_{2}\left(\mu_{4}, \eta^{2}-\mathrm{Se}_{2}\right)\right]$ & $2.4103(11)$ & $2.5799(11)$ & $65.88(3)$ & $1 b$ \\
\hline$\left[\mathrm{Hg}_{4}\left(\mathrm{Se}_{2}\right)_{2}\left(\mathrm{PSe}_{4}\right)_{4}\right]^{8-}$ & $2.416(4)$ & - & 84.07 & $14 \mathrm{c}$ \\
\hline$\left[\mathrm{Et}_{4} \mathrm{~N}\right]_{4}\left[\mathrm{Se}_{6} \mathrm{Mn}_{6}(\mathrm{CO})_{18}\right]$ & $2.37(2)$ & - & $81.14(4)$ & $14 d$ \\
\hline$\left[\mathrm{Et}_{4} \mathrm{~N}\right]_{4}\left[\mathrm{Se}_{10} \mathrm{Mn}_{6}(\mathrm{CO})_{18}\right]$ & $2.394(1)$ & $2.695(2)$ & $92.89(7)$ & $14 d$ \\
\hline$\left[\left\{\mathrm{Ru}_{2} \mathrm{Cl}_{2}(p \text {-cymene })_{2}\right\}_{2}\left(\mu_{4}, \eta^{2}-\mathrm{S}_{2}\right)\right], \mathbf{1}$ & $2.1089(8)$ & $2.9395(4)$ & 78.41 & $\begin{array}{l}\text { This } \\
\text { work }\end{array}$ \\
\hline
\end{tabular}

${ }^{\mathrm{a}}$ in $\AA \mathrm{A}^{\mathrm{b}} \mathrm{in}^{\circ}$ 

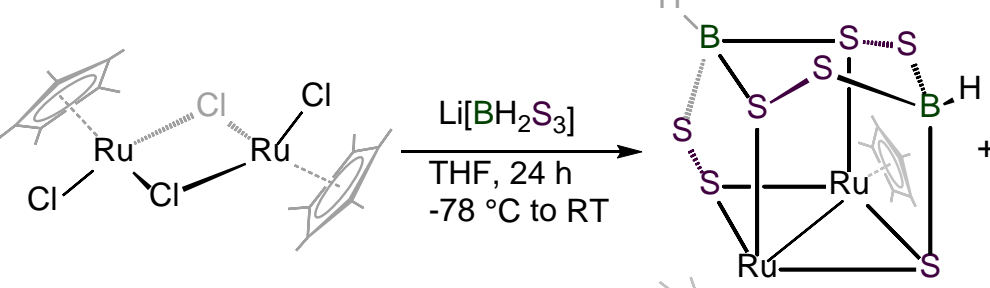

4
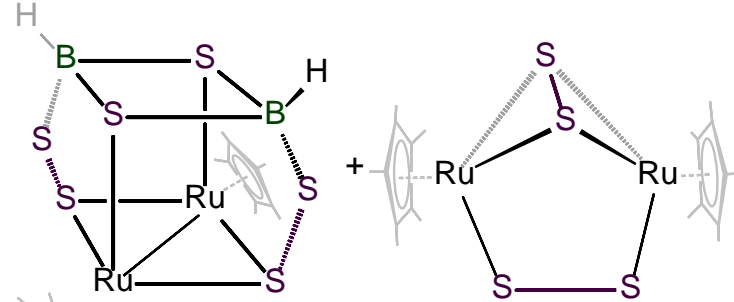

5

Scheme 2 Reaction of $[\mathrm{Cp} * \mathrm{Ru}(\mu-\mathrm{Cl}) \mathrm{Cl}]_{2}$ with $\mathrm{Li}\left[\mathrm{BH}_{2} \mathrm{~S}_{3}\right]$.

As shown in the Fig. 4a, the single-crystal X-ray structures of $\mathbf{4}$ and $\mathbf{5}$ revealed a tris-homocubane and bishomocubane alike cores, respectively. The occupancy ratio of molecules $\mathbf{4}$ and $\mathbf{5}$ in the structure is 0.62:0.38. The structures of $\mathbf{4}$ and $\mathbf{5}$ match well with the spectroscopic and mass spectrometric data that displayed the presence of two trithioborate $\left(\mathrm{HBS}_{3}\right)$ units. The presence of both types of sulfur atoms (two-coordinated sulfur and threecoordinated sulfur atoms) are observed and the two-coordinated sulfur atoms bridged over the three longer B-S edges in compound 4. The average S-S bond length of $2.059 \AA$ in 4 is smaller as compared to that of $\mathbf{1}$ (2.1089(8) $\AA$ ). The ruthenium atoms draw the sulfur atoms towards them more closely in $\mathbf{1}$ as compared to $\mathbf{4}$ and resulting the elongation of disulfide bond. The average $\angle \mathrm{B}-\mathrm{S}-\mathrm{S}$ in 4 is $106.93^{\circ}$ and is consistent with the obtuse sulfur bridge. The square Ru1-S3-Ru2-S4 face is slightly deviated from the plane with a dihedral angle of $9.60^{\circ}$. The Ru-Ru bond distance of 2.7804(5) $\AA$ is longer as compared to the ruthenium boryl complex $\left[(\mathrm{Cp} * \mathrm{Ru})_{2}\left(\mu, \eta^{2}: \eta^{2}-\mathrm{BHS}\right)(\mu\right.$ $\left.\left.\mathrm{SCH}_{2} \mathrm{SBH}\right)\right]^{13 b}(2.6388(10) \AA ̊ \AA)$ but smaller than the ruthenaborane complex $\left[\left(\mathrm{RuCp}^{*}\right)_{2}\left\{\mu-\mathrm{Se}_{6}(\mathrm{BH})_{2}\right\}\right]^{20}(2.877(4) \AA)$. On the other hand, compound 5 resembled the 1,3-isomer of $\left[\left(\mathrm{RuCp}^{*}\right)_{2}\left\{\mu-\mathrm{Se}_{6}(\mathrm{BH})_{2}\right\}\right]^{20}$, in which six sulfur atoms are two and three coordinated. The average S-S bond distance of $2.0275 \AA$ of the disulfide units is shorter than $\mathrm{S}_{8}$ $(2.037(5) \AA)$. Two boron centers in $\mathbf{5}$ are tetrahedrally bonded by three sulfur and one hydrogen atoms. The Ru1Ru2 bond distance of 2.7804(5) $\AA$ in 5 is shorter as compared to that of another bis-homocubane analogue $\left[\left(\mathrm{RuCp}^{*}\right)_{2}\left\{\mu-\mathrm{Se}_{6}(\mathrm{BH})_{2}\right\}\right]^{20}(2.877(4) \AA ̊ \AA)$. The average $\mathrm{B}-\mathrm{S}$ distance in $\mathbf{5}(1.9518 \AA$ ) $)$ is shorter than the boryl complex $\left[\left(\mathrm{RuCp}^{*}\right)_{2}\left(\mu-\mathrm{SBHS}-\kappa^{1} \mathrm{~B}: k^{2} \mathrm{~S}: k^{2} \mathrm{~S}\right)\left(\mu, \eta^{1}: \eta^{1}-\mathrm{S}_{2}\right)\right]^{11}(1.8235 \AA)$. Unlike 1,3-bis-homocubane isomer core, the core of 1,4isomer comprising ruthenium, boron and chalcogen atoms are exceptional and therefore $\mathbf{5}$ is a distinguished entry to the family of bis-homocubane derivatives.

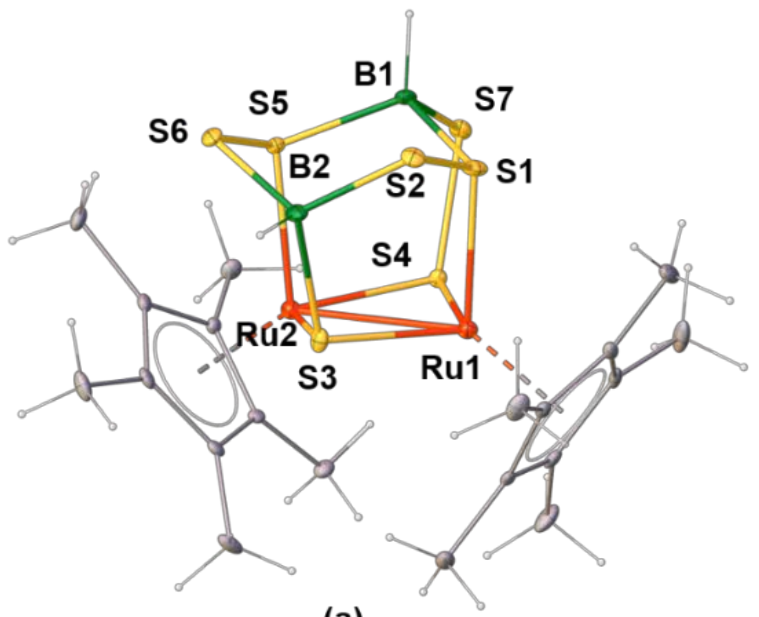

(a)

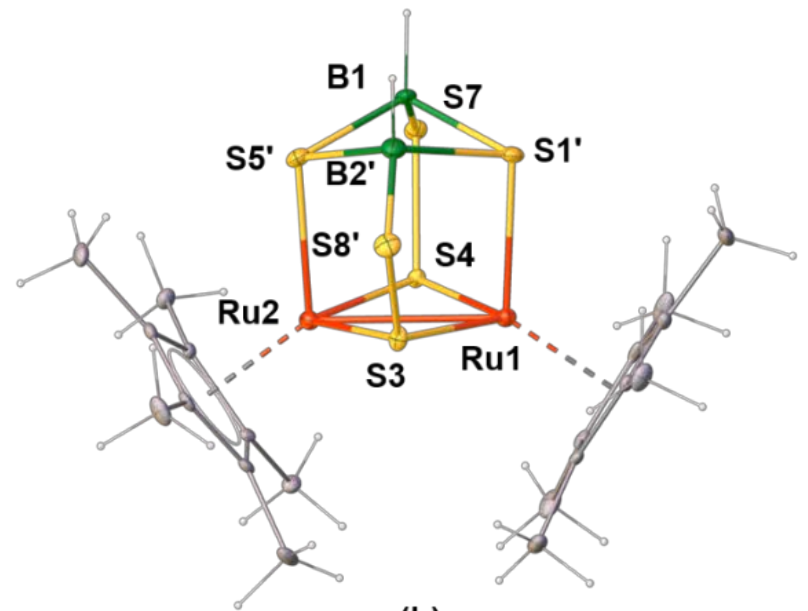

(b)

Fig. 4. Molecular structures of (a) 4 and (b) 5. Selected bond lengths ( $(\AA)$ and bond angles ( ${ }^{\circ}$ ). 4: B1-S1 1.932(5), B1S5 1.946(11), B1-S7 1.868(6), B2-S2 1.866(13), B2-S3 2.095(12), B2-S6 1.866(14), S1-S2 2.013(2), S5-S6 2.052(14), S4-S7 2.1130(15), Ru1-S1 2.3637(11), Ru1-S3 2.2976(11), Ru1-S4 2.2927(10), Ru2-S3 2.3049(11), Ru2-S4 2.2875(10), Ru2-S5 2.356(12), Ru1-Ru2 2.7804(5), S1-B1-S5 108.8(5), S1-B1-S7 106.6(3), S5-B1-S7 104.8(5). 5: B1-S1' 1.932(5), B1-S5' 1.91(2), B2'-S1' 2.165(16), B2'-S5' 2.02(3), B2'-S8' 1.816(17), S3-S8' 1.942(5), Ru1-S1' 2.3637(11), Ru2-S5' 2.39(2); S1'-B2'-S5' 92.5(8), S5'-B2'-S8' 114.0(10). 
Table 2 Selected spectroscopic and structural parameters of bis- and tris-homocubane analogues.

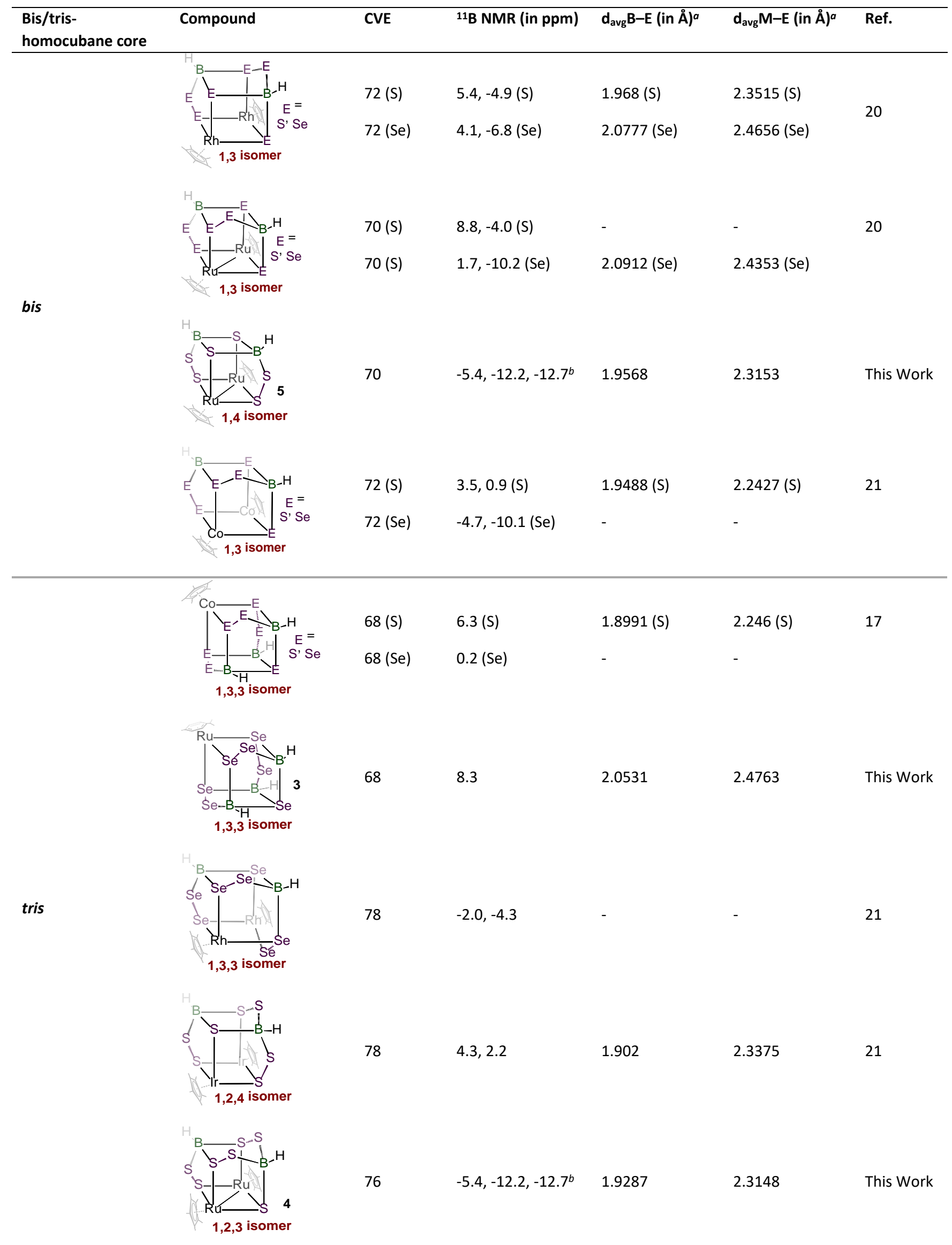

$a^{a}=$ chalcogen, $\mathrm{CVE}=$ cluster valence electron count, avg = average, $-=$ data is not available, ${ }^{b}=$ combined spectrum of $\mathbf{4}$ and $\mathbf{5}$. 


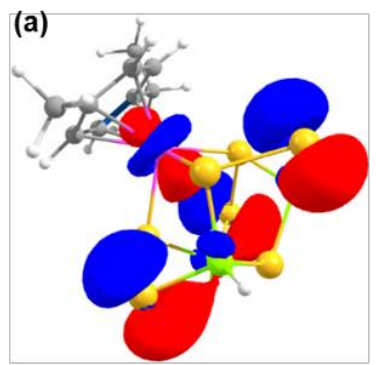

HOMO-3

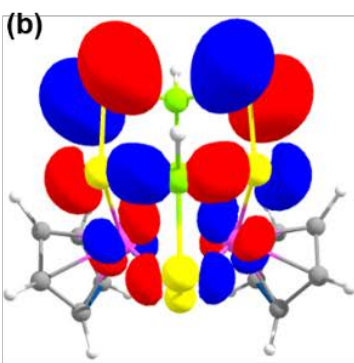

HOMO

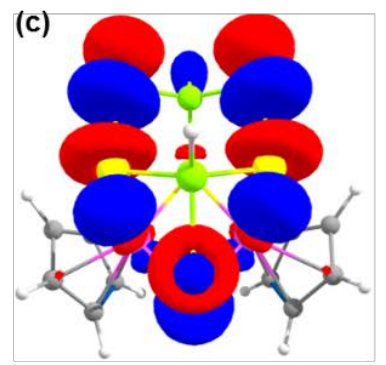

LUMO+6

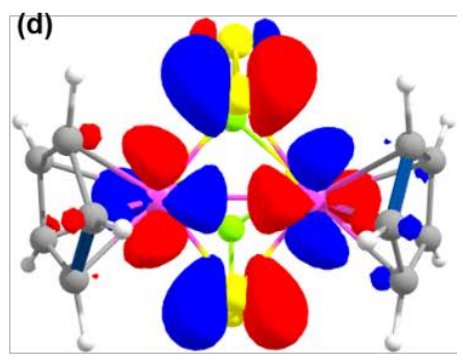

LUMO

Fig. 5 Selected frontier molecular orbitals of tris-homocubane analogues 3 (a) and 4' (b, c) and bis-homocubane analogue $5^{\prime}(d)$.

In order to understand the bonding situation, the DFT based theoretical calculations were performed for $\mathbf{3}, \mathbf{4}^{\prime}$ and $5^{\prime}$ (4' and $\mathbf{5}^{\prime}$ are the $\mathrm{Cp}$ analogues of 4 and $\mathbf{5}$, respectively). The experimental data were compared with the theoretical ones of $\mathbf{3}, \mathbf{4}^{\prime}$ and $\mathbf{5}^{\prime}$ that revealed similar bond lengths. The molecular orbital $(\mathrm{MO})$ analysis revealed that the nonbonding $d$ orbitals of metal and $p$ orbitals of two-coordinated Se atoms were localized in HOMO and HOMO3 of compound 3 (Fig. $5 \mathrm{a}$ ). The HOMO of $4^{\prime}$ displayed the presence of non-bonding metal $d$ orbitals along with two types of interactions. For example, (i) $\sigma$-bonding interaction between the $p$ orbitals of two-coordinated $\mathrm{S}$ and $\mathrm{B}$ atoms and (ii) the $\pi$-antibonding interaction between the two-coordinated $\mathrm{S}$ and three-coordinated $\mathrm{S}$ atoms (Fig. $5 b)$. In addition, the $\sigma$-antibonding overlaps along the three disulfide bonds were observed in LUMO+6 of 4' (Fig. 5c). In case of $5^{\prime}$, the HOMO-1 revealed the presence of nonbonding orbitals on each sulfur atoms where the size of the lobe of two connected atoms were bigger than three-coordinated $\mathrm{S}$ atoms. Considering all these interactions, we believe that the two-coordinated $\mathrm{E}$ atoms in $\mathbf{3}, \mathbf{4}^{\prime}$ and $\mathbf{5}^{\prime}$ are more potential to react with electrophiles as compared to the three-coordinated $\mathrm{E}$ atoms. Along with the localized $d$ orbitals of ruthenium centers, delocalization of the electron density over the non-planar S-B-S-B square face was observed in HOMO of compound $\mathbf{5}^{\prime}$. Likewise, the LUMO of $\mathbf{5}^{\prime}$ also comprised an extrapolated $\pi$-antibonding interaction among the $d$ and $p$ orbitals of the metal and sulfur atoms, respectively throughout the Ru-S-Ru-S square face (Fig. $5 \mathrm{~d}$ ). These interactions play a prominent role when any kind of bond making or bond breaking has been taken place due to further inclusion of the ligands. The theoretical calculations suggest that $\mathbf{3}$ can react through its labile S-S bonds, whereas $\mathbf{4}$ and $\mathbf{5}$ can react both through its square faces and reactive disulfide bonds.

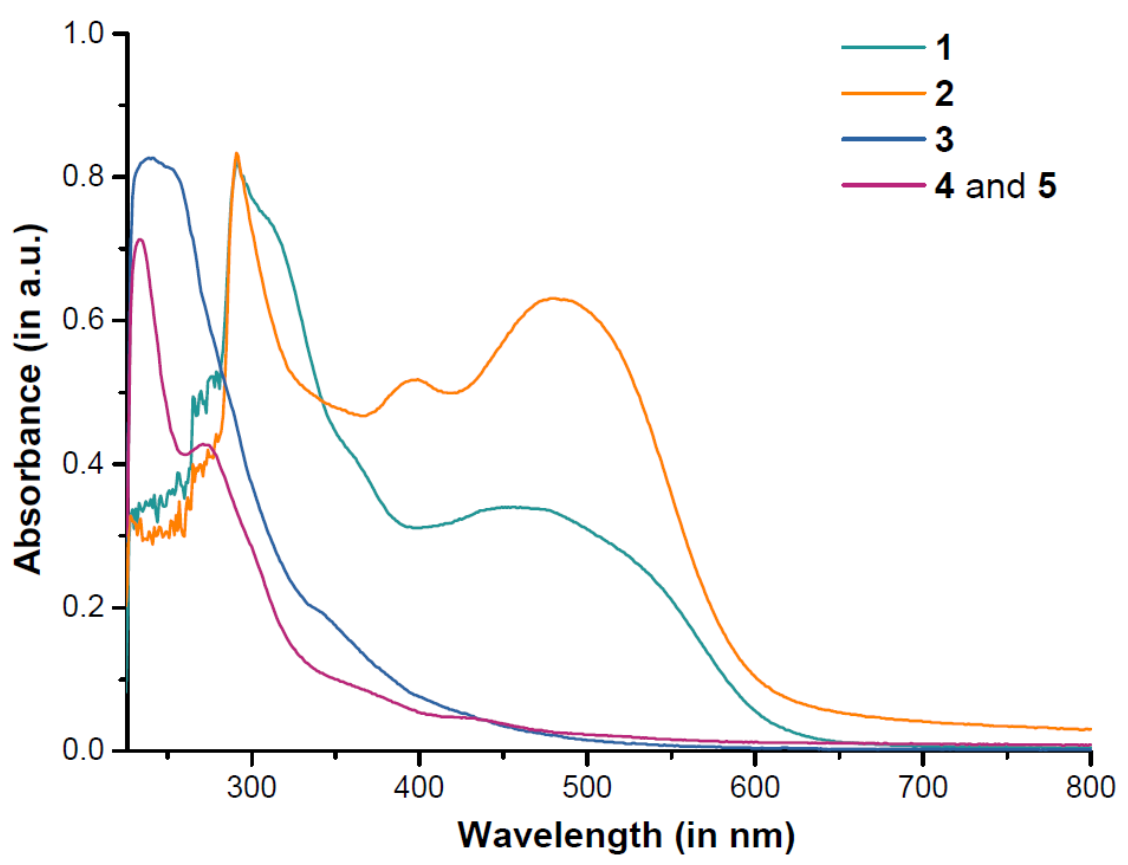

Fig. 6 Combined UV-vis spectra of 1, 2, 3, 4 and 5 in $\mathrm{CH}_{2} \mathrm{Cl}_{2}$ 
In order to compare the structural properties of the bis/tris-homocubane analogues and find out the influence of chalcogen atoms on the stability of these species, we have listed the spectroscopic and structural parameters of some selected bis- and tris-homocubane analogues in Table 2. ${ }^{17,20,21}$ Among the bis-homocubanes analogues, the 1,3-isomer of bis-homocubanes containing metal, chalcogen and boron atoms is generally known. However, compound $\mathbf{5}$ is a unique example of bis-homocubane analogue which was isolated as a 1,4-isomer. On the other hand, the tris-homocubane analogues ( 3 and $\mathbf{4}$ ) are observed as 1,3,3-and 1,2,3-isomers of the tris-homocubane analogues. The organic bis-homocubane $\left(\mathrm{C}_{10} \mathrm{H}_{12}\right)$ and tris-homocubane $\left(\mathrm{C}_{11} \mathrm{H}_{14}\right)$ are electron-precise compounds with the valence electron counts of 52 and 58 , respectively. Generally, the main group element and the transition metal follow the octet and 18-electron rule, respectively for these cubane derivatives. ${ }^{22}$ Most of the compounds listed in the Table 2 possess the expected electron counts. However, 4 and $\mathbf{5}$ possess 76 and 70 electrons, two lesser than 78 and 72 , respectively $(4: 2(\mathrm{Cp} * \mathrm{Ru}) \times 13+2(\mathrm{BH}) \times 4+7(\mathrm{~S}) \times 6=76 ; 5: 2(\mathrm{Cp} * \mathrm{Ru}) \times 13+2(\mathrm{BH}) \times 4+6(\mathrm{~S}) \times 6=70)$. The loss of two electrons is balanced due to the presence of one Ru-Ru bond. The ${ }^{11} \mathrm{~B}$ chemical shifts of these compounds lie within the range of $\delta-12.7$ to $8.8 \mathrm{ppm}$ that is typical for the trichalcogenato borate unit/s. The average $\mathrm{B}-\mathrm{E}$ and $\mathrm{M}-\mathrm{E}$ distances in these bis- and tris-homocubane analogues lie within the single bond distances.

The dichalcogenide complexes $\mathbf{1}$ and $\mathbf{2}$ show intense red color which can be explained by UV-Vis absorption spectroscopy. The UV-Vis absorption spectra for 1-5 were recorded in $\mathrm{CH}_{2} \mathrm{Cl}_{2}$ that show three absorption bands each (Fig. 6). An intense high energy absorption band around $291 \mathrm{~nm}$ is observed for both $\mathbf{1}$ and $\mathbf{2}$, which is assigned for the spin-allowed $\pi-\pi^{*}$ ligand-centered transitions localized in the $p$-cymene ligands. ${ }^{23}$ On the other hand, the low energy absorption bands in the range of $315-484 \mathrm{~nm}$ for $\mathbf{1}$ and $\mathbf{2}$ correspond to the spin-allowed metal to ligand charge transfer (MLCT) transitions. ${ }^{24}$ The ligands in $\mathbf{1}$ and $\mathbf{2}$ might have allowed an extended delocalization of the acceptor orbital of MLCT excited states. The intense lower energy peak at $529 \mathrm{~nm}$ for 1 can be useful for optical limiting applications. ${ }^{25}$ The energy of the HOMO associated with the metal centers followed a decreasing trend from $\mathbf{1}$ to $\mathbf{2}$ and that is reflected in the blue-shifted UV-Vis spectrum of $\mathbf{2}$. Moreover, the high-energy absorption bands around 230-270 $\mathrm{nm}$ correspond to the $\pi-\pi^{*}$ transition for the $p$-cymene and the Cp* ligands for $\mathbf{3}$ and $\mathbf{4 / 5}$, respectively. Fig. 6 displayed an intense absorption around $500 \mathrm{~nm}$ for $\mathbf{1 - 2}$ and this adsorption due to the interaction between the $\mathrm{Ru}_{2}$ centres through the bridging dichalcogenide ligand. The low-energy bands around 341 and 436 $\mathrm{nm}$ were also observed for $\mathbf{3}$ and $\mathbf{4 / 5}$, respectively, that may be assigned to the charge transfer bands.

\section{Conclusions}

In this article, we have synthesized different ruthenium dichalcogenide species using different synthetic methods. We have efficiently demonstrated the reactivity of $\mathrm{Li}_{[}\left[\mathrm{BH}_{2} \mathrm{E}_{3}\right]\left(\mathrm{E}=\mathrm{S}\right.$ or Se) with $[(p \text {-cymene }) \mathrm{Ru}(\mu-\mathrm{Cl}) \mathrm{Cl}]_{2}$ that generated tetrametallic dichalcogenide complexes. In these complexes, the dichalcogenide $\left(E_{2}{ }^{2-}\right)$ unit is stabilized by $\{(p \text {-cymene }) R u\}_{4}$ unit. The detailed theoretical investigation on 1-2' explicitly revealed the bonding and shed light on the true nature of the $\mathrm{E}-\mathrm{E}$ bond. The theoretical studies revealed the dianionic nature of the $\mathrm{E}-\mathrm{E}$ ligand in these tetrametallic complexes and also confirmed the presence of subtle metal-metal bonding interactions in these complexes which indicated lability of the Ru-Ru bonds. The intrinsic electronic properties of these species were demonstrated by UV-Vis spectroscopy that reveals a low-energy absorbance due to MLCT transitions. Investigations to evaluate the scope of synthesis of dichalcogenide complexes concerning early transition metals are underway.

\section{Author Contributions}

The manuscript was written through contributions of all authors. All authors have given approval to the final version of the manuscript, which was prepared through contribution of all the authors.

\section{Conflicts of interest}

There are no conflicts to declare.

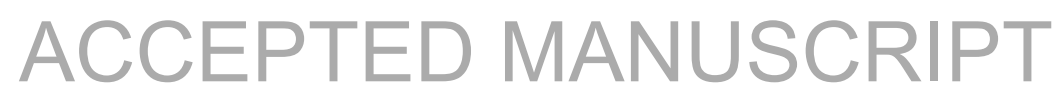




\section{Acknowledgements}

This work was supported by the Indo-French Center for the Promotion of Advanced Research (IFCPAR-CEFIPRA), Grant No. 5905-1, New Delhi, India. S. G. thanks, CSIR, India, for the research fellowship.

\section{Experimental Details}

\section{General procedures and instrumentation}

All the syntheses were performed under argon atmosphere using standard Schlenk line and glove box techniques and all the solvents were purified by distillation method in presence of proper drying agents. $\mathrm{CDCl}_{3}$ was degassed through three freeze-pump-thaw cycles. The starting materials $\left[\left(p \text {-cymene) } \mathrm{RuCl}_{2}\right]_{2}{ }^{26}\left[\mathrm{Cp}^{2} \mathrm{RuCl}_{2}\right]_{2}{ }^{27}\right.$ and $\mathrm{Li}^{2}\left[\mathrm{BH}_{2} \mathrm{E}_{3}\right]^{5}$ were synthesized following the corresponding literature. All the syntheses reported here are reproducible. These reactions were performed multiple times which gave same product distribution. Thin-layer chromatography was performed using $250 \mathrm{~mm}$ aluminium supported silica gel TLC plates. Chemical shifts are referenced to residual solvent signals $\left({ }^{1} \mathrm{H} /{ }^{13} \mathrm{C}\left\{{ }^{1} \mathrm{H}\right\} ; \mathrm{CDCl}_{3}: \delta=7.26 / 77.16 \mathrm{ppm}\right)$. For the ${ }^{11} \mathrm{~B}\left\{{ }^{1} \mathrm{H}\right\} \mathrm{NMR},\left[\mathrm{Bu}_{4} \mathrm{~N}\left(\mathrm{~B}_{3} \mathrm{H}_{8}\right)\right]^{28}$ prepared in $\mathrm{d}_{6}$-benzene was taken in a sealed tube $\left(\delta_{\mathrm{B}}, \mathrm{ppm},-30.07\right)$ and used as an external reference. The 6545 Qtof LC/MS instrument was used for recording mass spectra. The infrared spectra and UV-vis spectra of all compounds were recorded on a Jasco FTIR-4100 spectrometer and a Thermo Scientific Evolution UV-vis spectrometer, respectively.

\section{Synthesis of 1}

A freshly prepared solution of four equivalents $\left[\mathrm{LiBH}_{2} \mathrm{~S}_{3}\right]$ was added dropwise in the toluene $(20 \mathrm{~mL})$ solution of $[(p$ cymene $) \mathrm{Ru}(\mu-\mathrm{Cl}) \mathrm{Cl}]_{2},(0.05 \mathrm{~g}, 0.082 \mathrm{mmol})$, taken in a flame dried Schlenk tube, over $15 \mathrm{~min}$ at $-78^{\circ} \mathrm{C}$. The reaction mixture was stirred vigorously and kept in room temperature for 6 hours. Then, the solvent was dried using vacuum and the solid deposit was extracted using the hexane/THF (95:5 v/v) solution mixture and ran through a G3 sintered frit partially filled with celite. Then, the volatiles were removed under vacuum and the chromatographic workup was carried out on a silica gel TLC plates using the solid residue. The hexane was used as an eluent and that allowed us to isolate red $1(0.006 \mathrm{~g}, 6 \%)$.

1: ${ }^{1} \mathrm{H}$ NMR $\left(500 \mathrm{MHz}, \mathrm{CDCl}_{3}, 22{ }^{\circ} \mathrm{C}\right): \delta=7.11\left(\mathrm{~d},{ }^{3} \mathrm{~J}_{\mathrm{HH}}=4.5 \mathrm{~Hz}, 2 \times 1 \mathrm{H} ; \mathrm{H}_{\mathrm{Ar}(p-\mathrm{cym})}\right), 6.91\left(\mathrm{~d},{ }^{3} \mathrm{HHH}_{\mathrm{H}}=6.4 \mathrm{~Hz}, 2 \times 1 \mathrm{H} ; \mathrm{H}_{\mathrm{Ar}(p-\mathrm{cym})}\right)$, $6.12\left(\mathrm{~d},{ }^{3} J_{\mathrm{HH}}=5.3 \mathrm{~Hz}, 2 \times 1 \mathrm{H} ; \mathrm{H}_{\operatorname{Ar}(p-c y m)}\right), 5.63\left(\mathrm{~d},{ }^{3} J_{\mathrm{HH}}=4.5 \mathrm{~Hz}, 2 \times 1 \mathrm{H} ; \mathrm{H}_{\operatorname{Ar}(p-\operatorname{cym})}\right), 5.46\left(\mathrm{~d},{ }^{3} \mathrm{~J}_{\mathrm{HH}}=6.4 \mathrm{~Hz}, 2 \times 1 \mathrm{H} ; \mathrm{H}_{\mathrm{Ar}(p-c y m)}\right)$, $5.23\left(\mathrm{~d},{ }^{3} J_{\mathrm{HH}}=5.8 \mathrm{~Hz}, 2 \times 1 \mathrm{H} ; \mathrm{H}_{\mathrm{Ar}(p-c y m)}\right), 4.53\left(\mathrm{~d},{ }^{3} J_{\mathrm{HH}}=5.8 \mathrm{~Hz}, 2 \times 1 \mathrm{H} ; \mathrm{H}_{\mathrm{Ar}(p-c y m)}\right), 4.31\left(\mathrm{~d},{ }^{3} J_{\mathrm{HH}}=5.3 \mathrm{~Hz}, 2 \times 1 \mathrm{H} ; \mathrm{H}_{\mathrm{Ar}(p-c y m)}\right)$, $3.30\left(\mathrm{sept},{ }^{3} \mathrm{~J}_{\mathrm{HH}}=6.8 \mathrm{~Hz}, 2 \times 1 \mathrm{H} ; \mathrm{HC}_{\mathrm{iPr}}\right), 2.93\left(\mathrm{sept},{ }^{3} \mathrm{JHH}_{\mathrm{HH}}=6.7 \mathrm{~Hz}, 2 \times 1 \mathrm{H} ; \mathrm{HC}_{\mathrm{iPr}}\right), 2.72\left(\mathrm{~s}, 2 \times 3 \mathrm{H} ; \mathrm{H}_{3} \mathrm{C}\right), 1.68\left(\mathrm{~s}, 2 \times 3 \mathrm{H} ; \mathrm{H}_{3} \mathrm{C}\right)$, $1.65\left(\mathrm{~d},{ }^{3} \mathrm{~J}_{\mathrm{HH}}=6.6 \mathrm{~Hz}, 3 \mathrm{H} ; \mathrm{H}_{3} \mathrm{C}_{\mathrm{iPr}}\right), 1.61\left(\mathrm{~d},{ }^{3} J_{\mathrm{HH}}=6.6 \mathrm{~Hz}, 3 \mathrm{H} ; \mathrm{H}_{3} \mathrm{C}_{\mathrm{iPr}}\right), 1.46\left(\mathrm{~d},{ }^{3} \mathrm{JHH}_{\mathrm{HH}}=6.6 \mathrm{~Hz}, 3 \mathrm{H} ; \mathrm{H}_{3} \mathrm{C}_{\mathrm{iPr}}\right), 1.36 \mathrm{ppm}\left(\mathrm{d},{ }^{3} J_{\mathrm{HH}}\right.$ $\left.=6.7 \mathrm{~Hz}, 3 \mathrm{H} ; \mathrm{H}_{3} \mathrm{C}_{\text {ipr }}\right) ;{ }^{13} \mathrm{C}\left\{{ }^{1} \mathrm{H}\right\} \mathrm{NMR}\left(125 \mathrm{MHz}, \mathrm{CDCl}_{3}, 22{ }^{\circ} \mathrm{C}\right): \delta=111.3,108.3,107.7,94.9\left(\mathrm{~s} ; \mathrm{C}_{p \text {-cym }}\right), 93.3,89.4,88.7$, 88.4, 82.3, 81.4, 80.4, 78.3 (s; $\left.\mathrm{HC}_{p-c y m}\right), 32.9,31.7$ (s; $\mathrm{HC}_{\text {ipr }}$ ), 25.1, $25.0\left(\mathrm{~s} ; \mathrm{H}_{3} \mathrm{C}_{\text {ipr }}\right.$ ), 20.4, $19.6 \mathrm{ppm}\left(\mathrm{s} ; \mathrm{H}_{3} \mathrm{C}\right)$; UV-Vis $\left(\mathrm{CH}_{2} \mathrm{Cl}_{2}, \lambda, \mathrm{nm}\right): 291,315,463,529$.

\section{Synthesis of 2 and 3}

A freshly prepared solution of four equivalent $\left[\mathrm{LiBH}_{2} \mathrm{Se}_{3}\right]$ was added dropwise in the toluene $(20 \mathrm{~mL})$ solution of $[(p$ cymene $) \mathrm{Ru}(\mu-\mathrm{Cl}) \mathrm{Cl}]_{2},(0.05 \mathrm{~g}, 0.082 \mathrm{mmol})$, taken in a flame dried Schlenk tube, over $15 \mathrm{~min}$ at $-78^{\circ} \mathrm{C}$. The reaction mixture was stirred vigorously and kept in room temperature for 6 hours. Then, the solvent was dried using vacuum and the solid deposit was extracted using the hexane/thf $(95: 5 \mathrm{v} / \mathrm{v})$ solution mixture and ran through a $\mathrm{G} 3$ sintered frit partially filled with celite. Then, the volatiles were removed under vacuum and the chromatographic workup was carried out on a silica gel TLC plates using the solid residue. The hexane was used as an eluent and that allowed us to isolate red $\mathbf{2}(0.005 \mathrm{~g}, 5 \%)$ and orange $\mathbf{3}(0.026 \mathrm{~g}, 38 \%)$.

2: MALDI-TOF calcd for $\mathrm{C}_{40} \mathrm{H}_{58} \mathrm{Ru}_{4} \mathrm{Se}_{2} \mathrm{Cl}_{4}{ }^{2+}[\mathrm{M}+2 \mathrm{H}]^{2+} \mathrm{m} / \mathrm{z}$ 1245.8, found $1245.8 ;{ }^{1} \mathrm{H}$ NMR $\left(400 \mathrm{MHz}, \mathrm{C}_{6} \mathrm{D}_{6}, 22{ }^{\circ} \mathrm{C}\right): \delta=$ $7.75\left(\mathrm{~d},{ }^{3} J_{\mathrm{HH}}=7.9 \mathrm{~Hz}, 2 \times 1 \mathrm{H} ; \mathrm{H}_{\mathrm{Ar}(p-\mathrm{cym})}\right), 7.71\left(\mathrm{~d},{ }^{3} J_{\mathrm{HH}}=7.4 \mathrm{~Hz}, 2 \times 1 \mathrm{H} ; \mathrm{H}_{\mathrm{Ar}(p-\mathrm{cym})}\right), 5.01\left(\mathrm{~d},{ }^{3} \mathrm{~J}_{\mathrm{HH}}=5.7 \mathrm{~Hz}, 2 \times 1 \mathrm{H} ; \mathrm{H}_{\text {Ar }(p-c y m)}\right)$, $4.88\left(\mathrm{~d},{ }^{3} J_{\mathrm{HH}}=5.4 \mathrm{~Hz}, 2 \times 1 \mathrm{H} ; \mathrm{H}_{\text {Ar }(p-c y m)}\right), 4.75\left(\mathrm{~d},{ }^{3} J_{\mathrm{HH}}=5.4 \mathrm{~Hz}, 2 \times 1 \mathrm{H} ; \mathrm{H}_{\mathrm{Ar}(p-c y m)}\right), 4.59\left(\mathrm{~d},{ }^{3} J_{\mathrm{HH}}=5.7 \mathrm{~Hz}, 2 \times 1 \mathrm{H} ; \mathrm{H}_{\mathrm{Ar}(p-c y m)}\right)$, $4.56\left(\mathrm{~d},{ }^{3} J_{\mathrm{HH}}=5.9 \mathrm{~Hz}, 2 \times 1 \mathrm{H} ; \mathrm{H}_{\mathrm{Ar}(p-c y m)}\right), 4.49\left(\mathrm{~d},{ }^{3} J_{\mathrm{HH}}=5.2 \mathrm{~Hz}, 2 \times 1 \mathrm{H} ; \mathrm{H}_{\mathrm{Ar}(p-c y m)}\right), 2.69\left(\mathrm{sept},{ }^{3} \mathrm{JHH}_{\mathrm{HH}}=6.6 \mathrm{~Hz}, 2 \times 1 \mathrm{H} ; \mathrm{HC}_{\mathrm{ipr}}\right)$, 
$1.98\left(\mathrm{~s}, 2 \times 3 \mathrm{H} ; \mathrm{H}_{3} \mathrm{C}\right), 1.78\left(\mathrm{~s}, 2 \times 3 \mathrm{H} ; \mathrm{H}_{3} \mathrm{C}\right), 1.70\left(\mathrm{~d},{ }^{3} \mathrm{~J}_{\mathrm{HH}}=5.4 \mathrm{~Hz}, 3 \mathrm{H} ; \mathrm{H}_{3} \mathrm{C}_{\text {ipr }}\right), 1.62\left(\mathrm{~d},{ }^{3} \mathrm{JHH}_{\mathrm{HH}}=5.9 \mathrm{~Hz}, 3 \mathrm{H} ; \mathrm{H}_{3} \mathrm{C}_{\text {ipr }}\right), 1.08(\mathrm{~d}$, $\left.{ }^{3} J_{\mathrm{HH}}=6.9 \mathrm{~Hz}, 3 \mathrm{H} ; \mathrm{H}_{3} \mathrm{C}_{\mathrm{iPr}}\right), 1.05 \mathrm{ppm}\left(\mathrm{d},{ }^{3} \mathrm{~J}_{\mathrm{HH}}=6.4 \mathrm{~Hz}, 3 \mathrm{H} ; \mathrm{H}_{3} \mathrm{C}_{\mathrm{iPr}}\right) ;{ }^{13} \mathrm{C}\left\{{ }^{1} \mathrm{H}\right\} \mathrm{NMR}\left(100 \mathrm{MHz}, \mathrm{C}_{6} \mathrm{D}_{6}, 22{ }^{\circ} \mathrm{C}\right): \delta=88.6\left(\mathrm{~s} ; \mathrm{C}_{p-}\right.$ cym), 88.3 (s; $\left.\mathrm{HC}_{p \text {-cym }}\right), 37.6$ (s; $\mathrm{HC}_{\text {ipr }}$ ), 32.4 (s; $\left.\mathrm{H}_{3} \mathrm{C}_{\mathrm{ipr}}\right), 27.6$ ppm (s; $\left.\mathrm{H}_{3} \mathrm{C}\right) ; \mathrm{UV}-\mathrm{Vis}\left(\mathrm{CH}_{2} \mathrm{Cl}_{2}, \lambda, \mathrm{nm}\right): 291,396,484$.

3: ESI-MS calcd for $\mathrm{C}_{12} \mathrm{H}_{20} \mathrm{~B}_{3} \mathrm{RuNSe}_{7}^{+}\left[\mathrm{M}+\mathrm{CH}_{3} \mathrm{CN}\right]^{+} \mathrm{m} / z$ 864.5, found 864.6; ${ }^{11} \mathrm{~B}\left\{{ }^{1} \mathrm{H}\right\} \mathrm{NMR}\left(160 \mathrm{MHz}, \mathrm{CDCl}_{3}, 22{ }^{\circ} \mathrm{C}\right): \delta=$ $-7.2(\mathrm{br}, 3 \mathrm{~B}) ;{ }^{1} \mathrm{H}$ NMR $\left(400 \mathrm{MHz}, \mathrm{CDCl}_{3}, 22^{\circ} \mathrm{C}\right): \delta=7.73\left(\mathrm{~d},{ }^{3} \mathrm{~J}_{\mathrm{HH}}=5.0 \mathrm{~Hz}, 1 \mathrm{H} ; \mathrm{H}_{\mathrm{Ar}(p-\operatorname{cym})}\right), 7.72\left(\mathrm{~d},{ }^{3} \mathrm{~J}_{\mathrm{HH}}=5.7 \mathrm{~Hz}, 1 \mathrm{H} ; \mathrm{H}_{\mathrm{Ar}(p-}\right.$ cym) ), $7.54\left(\mathrm{~d},{ }^{3} J_{\mathrm{HH}}=5.1 \mathrm{~Hz}, 1 \mathrm{H} ; \mathrm{H}_{\mathrm{Ar}(p-\mathrm{cym})}\right), 7.53\left(\mathrm{~d},{ }^{3} J_{\mathrm{HH}}=5.5 \mathrm{~Hz}, 1 \mathrm{H} ; \mathrm{H}_{\mathrm{Ar}(p-c y m)}\right), 4.28\left(\mathrm{br}, 3 \mathrm{H} ; \mathrm{BH}_{t}\right), 2.04$ (sept, ${ }^{3} J_{\mathrm{HH}}=6.8$ $\left.\mathrm{Hz}, 1 \mathrm{H} ; \mathrm{HC}_{\text {ipr }}\right), 0.99 \mathrm{ppm}\left(\mathrm{d},{ }^{3} \mathrm{JHH}_{\mathrm{HH}}=6.7 \mathrm{~Hz}, 3 \times 3 \mathrm{H} ; \mathrm{H}_{3} \mathrm{C}\right.$ and $\left.\mathrm{H}_{3} \mathrm{C}_{\text {iPr }}\right) ;{ }^{13} \mathrm{C}\left\{{ }^{1} \mathrm{H}\right\} \mathrm{NMR}\left(100 \mathrm{MHz}, \mathrm{CDCl}_{3}, 22{ }^{\circ} \mathrm{C}\right): \delta=167.9$, $132.6\left(\mathrm{~s} ; \mathrm{C}_{p \text {-cym }}\right), 131.1,129.0,77.4,71.9\left(\mathrm{~s} ; \mathrm{HC}_{p-c y m}\right), 27.9(\mathrm{~s} ; \mathrm{HC}$ ipr $), 23.0\left(\mathrm{~s} ; \mathrm{H}_{3} \mathrm{C}_{\text {ipr }}\right), 19.3 \mathrm{ppm}\left(\mathrm{s} ; \mathrm{H}{ }_{3} \mathrm{C}\right) ; \mathrm{UV}-\mathrm{Vis}\left(\mathrm{CH}_{2} \mathrm{Cl}_{2}\right.$, $\lambda, \mathrm{nm}): 240,253,341 ; \mathrm{IR}\left(\mathrm{CH}_{2} \mathrm{Cl}_{2}, \tilde{v}, \mathrm{~cm}^{-1}\right): 2437\left(\mathrm{BH}_{t}\right)$.

\section{Syntheses of 4 and 5}

A freshly prepared solution of four equivalents $\left[\mathrm{LiBH}_{2} \mathrm{~S}_{3}\right]$ was added dropwise in the toluene $(20 \mathrm{~mL})$ solution of $[\mathrm{Cp} * \mathrm{Ru}(\mu-\mathrm{Cl}) \mathrm{Cl}]_{2},(0.05 \mathrm{~g}, 0.081 \mathrm{mmol})$, taken in a flame dried Schlenk tube, over $15 \mathrm{~min}$ at $-78^{\circ} \mathrm{C}$. The reaction mixture was stirred vigorously and kept in room temperature for 24 hours. Then, the solvent was dried using vacuum and the solid deposit was extracted using the hexane $/ \mathrm{CH}_{2} \mathrm{Cl}_{2}(70: 30 \mathrm{v} / \mathrm{v})$ solution mixture and ran through a G3 sintered frit partially filled with celite. Then, the volatiles were removed under vacuum and the chromatographic workup was carried out on a silica gel TLC plates using the solid residue. The hexane $/ \mathrm{CH}_{2} \mathrm{Cl}_{2}(60: 40$ $\mathrm{v} / \mathrm{v}$ ) mixture was used as eluent and that allowed us to isolate yellow mixture of $\mathbf{4}$ and $\mathbf{5}(0.012 \mathrm{~g}, 21 \%)$ along with $\left[(\operatorname{RuCp})_{2}\left(\mu, \eta^{2}: \eta^{2}-\mathrm{S}_{2}\right)\left(\mu, \eta^{1}: \eta^{1}-\mathrm{S}_{2}\right)\right]$ and $\left[(\mathrm{RuCp})_{2}\left(\mu-\mathrm{SBHS}-\kappa^{1} \mathrm{~B}: \kappa^{2} \mathrm{~S}: \kappa^{2} \mathrm{~S}\right)\left(\mu, \eta^{1}: \eta^{1}-\mathrm{S}_{2}\right)\right]$.

Combined spectroscopic data for 4 and 5: HR-MS (ESI) ${ }^{+}$calcd. for $\mathrm{C}_{20} \mathrm{H}_{33} \mathrm{Ru}_{2} \mathrm{~S}_{7} \mathrm{~B}_{2} \mathrm{Na}^{+}[\mathrm{M}+\mathrm{Na}]^{+} \mathrm{m} / z$ 743.8742, found 743.8747 (4); calcd. for $\mathrm{C}_{21} \mathrm{H}_{37} \mathrm{Ru}_{2} \mathrm{~S}_{6} \mathrm{~B}_{2}{ }^{+}\left[\mathrm{M}+\mathrm{H}+\mathrm{CH}_{3} \mathrm{OH}\right]^{+} \mathrm{m} / \mathrm{z} 721.9465$, found $721.9436(5) ;{ }^{11} \mathrm{~B}\left\{{ }^{1} \mathrm{H}\right\} \mathrm{NMR}(160 \mathrm{MHz}$, $\left.\mathrm{CDCl}_{3}, 22^{\circ} \mathrm{C}\right): \delta=-5.4(\mathrm{br}, 2 \mathrm{~B}),-12.2(\mathrm{br}, 1 \mathrm{~B}),-12.7(\mathrm{br}, 1 \mathrm{~B}) ;{ }^{1} \mathrm{H} \mathrm{NMR}\left(500 \mathrm{MHz}, \mathrm{CDCl}_{3}, 22^{\circ} \mathrm{C}\right): \delta=1.79,1.74(\mathrm{~s}, 2 \times 30 \mathrm{H}$, $\left.\mathrm{Cp}^{*}\right) ;{ }^{13} \mathrm{C}\left\{{ }^{1} \mathrm{H}\right\}$ NMR $\left(125 \mathrm{MHz}, \mathrm{CDCl}_{3}, 22{ }^{\circ} \mathrm{C}\right): \delta=99.4,97.8$ (s, $\left.\mathrm{C}_{5} \mathrm{Me}_{5}\right), 10.5,10.4$ (s, $\left.\mathrm{C}_{5} \mathrm{Me}_{5}\right) ; \mathrm{UV}-\mathrm{Vis}\left(\mathrm{CH}_{2} \mathrm{Cl}_{2}, \lambda, \mathrm{nm}\right):$ 232,271, 436; IR $\left(\mathrm{CH}_{2} \mathrm{Cl}_{2}, \tilde{v}, \mathrm{~cm}^{-1}\right): 2448\left(\mathrm{BH}_{t}\right)$.

\section{Computational Details}

All molecules were fully optimized with the Gaussian 16 program ${ }^{29}$ using the gradient-corrected B3LYP functional in conjunction with the 6-31g(d)-SDD basis set from EMSL Basis Set Exchange Library. The model compounds were fully optimized in gaseous state (no solvent effect) starting from the X-ray crystallographic coordinates. Frequency calculations were performed at the same level of theory to verify the nature of the stationary state and the absence of any imaginary frequency confirmed that all structures represent minima on the potential energy hypersurface. Further, gauge including atomic orbital $(\mathrm{GIAO})^{30}$ method has been employed to compute the ${ }^{11} \mathrm{~B}$ chemical shifts. The NMR chemical shifts were calculated using the hybrid Becke-Lee-Yang-Parr (B3LYP) functional ${ }^{31}$ and 6-31g(d)SDD basis set on the B3LYP/6-31g(d)-SDD optimized geometries. The ${ }^{11} \mathrm{~B}$ NMR chemical shifts were calculated relative to $\mathrm{B}_{2} \mathrm{H}_{6}$ (B3LYP $B$ shielding constant $80.05 \mathrm{ppm}$ ) and converted to the usual $\left[\mathrm{BF}_{3} . \mathrm{OEt}_{2}\right]$ scale using the experimental $\delta\left({ }^{11} \mathrm{~B}\right)$ value of $\mathrm{B}_{2} \mathrm{H}_{6}, 16.6 \mathrm{ppm} .{ }^{32}$ Natural bonding analyses were performed with the natural bond orbital (NBO) partitioning scheme as implemented in the Gaussian 16 suite of programs. ${ }^{33}$ Wiberg bond indexes (WBI) were obtained on natural bond orbital analysis. In order to understand the nature of bonding in the synthesised molecules in greater detail, the topological properties of the resultant electron density, $\rho$, obtained from the wave functions of all the optimized structures were analyzed with the quantum theory of atoms in molecules (QTAIM). ${ }^{34}$ The QTAIM analysis were carried out utilizing Multiwfn V.3.6 package ${ }^{35}$ whereas the wave functions were generated with Gaussian09 at the same level of theory as was used for geometry optimization. All the optimized structures and orbital graphics were generated using the Gaussview ${ }^{36}$ and Chemcraft $^{37}$ visualization programs. 


\section{X-ray Analysis Details}

Suitable crystals were grown through slow diffusion process of respective hexane- $\mathrm{CH}_{2} \mathrm{Cl}_{2}$ solutions of $\mathbf{1 ,} \mathbf{3}$ and 4, $\mathbf{5}$. D8 VENTURE Bruker AXS diffractometer with graphite monochromated Mo-K $\alpha(\lambda=0.71073 \AA$ ) radiation was used for collection and integration of crystal data of 1 at 150(2) K. Bruker AXS Kappa APEX2 CCD diffractometer with graphite monochromated Mo-K $\alpha(\lambda=0.71073 \AA)$ radiation was used for collection and integration of crystal data of 3 at 296(2) K. Bruker APEX2 CCD diffractometer with graphite monochromated Mo-K $\alpha(\lambda=0.71073 \AA$ A radiation was used for collection and integration of crystal data of 4 and 5 at 150(2) K. The structure of 1 was solved by heavy atom methods using SHELXT-2015 and refined using SHELXL-2018/3. ${ }^{38}$ The structure of $\mathbf{3}$ was solved by heavy atom methods using SIR92 ${ }^{39}$ and refined using SHELXL-2014/7. The structures of $\mathbf{4}$ and $\mathbf{5}$ were solved by heavy atom methods using SHELXS-97 and refined using SHELXL-2018/3. Olex ${ }^{2}$ software was used for drawing the molecular structures. ${ }^{40}$ The non-hydrogen atoms were refined with anisotropic displacement parameters. All the hydrogen atoms were fixed geometrically at chemically meaningful positions and were allowed to refine by riding model restraint. The $\mathrm{C}-\mathrm{H}$ distances used for fixing the hydrogen atoms of methine, aromatic and methyl groups are 1.0, 0.95, $0.98 \AA$ r respectively. The thermal parameters of methine and aromatic hydrogen atoms were assigned 1.2 times the $U_{\text {eq }}$ of the respective carbon atoms while the methyl hydrogen atoms were assigned 1.5 times $U_{\text {eq }}$ of the parent carbon. The distances B2-H2 and B2'-H2' of cocrystal 4 and 5 are fixed at 1.15(0.02) $\AA$ while all other B-H hydrogen atoms were allowed to refine with their thermal parameters restrained to be equal to the $U_{\text {eq }}$ of the respective boron atoms within the limits of standard deviations.

Table 3 Crystal data and structure refinement details for 1, 3, 4 and 5.

\begin{tabular}{|c|c|c|c|}
\hline Complex & 1 & 3 & 4 and 5 \\
\hline CCDC no. & 1974958 & 1974959 & 2073890 \\
\hline Empirical formula & $\mathrm{C}_{40} \mathrm{H}_{56} \mathrm{Cl}_{4} \mathrm{Ru}_{4} \mathrm{~S}_{2}$ & $\mathrm{C}_{10} \mathrm{H}_{17} \mathrm{~B}_{3} \mathrm{RuSe}_{7}$ & $\mathrm{C}_{20} \mathrm{H}_{32} \mathrm{~B}_{2} \mathrm{Ru}_{2} \mathrm{~S}_{6.62}$ \\
\hline Formula weight & 1147.04 & 823.45 & 708.45 \\
\hline Crystal system & Monoclinic & Monoclinic & Monoclinic \\
\hline Space group & $P 2_{1} / c$ & $P 2_{1} / c$ & $P 2 \sqrt{1} / n$ \\
\hline$a(\AA ̊)$ & $14.8508(15)$ & $8.264(3)$ & $9.7476(10)$ \\
\hline$b(\AA ̊)$ & $17.5180(18)$ & $17.571(7)$ & $14.5175(16)$ \\
\hline$c(\AA)$ & $18.851(2)$ & $14.898(5)$ & $18.5731(18)$ \\
\hline$\alpha\left({ }^{\circ}\right)$ & 90 & 90 & 90 \\
\hline$B\left({ }^{\circ}\right)$ & $106.413(4)$ & $101.254(16)$ & $95.722(4)$ \\
\hline$y\left({ }^{\circ}\right)$ & 90 & 90 & 90 \\
\hline$V\left(\AA^{3}\right)$ & $4704.4(9)$ & 2121.9(13) & $2615.2(5)$ \\
\hline Z & 4 & 4 & 4 \\
\hline$\rho_{\text {calcd }}\left(\mathrm{g} / \mathrm{cm}^{3}\right)$ & 1.620 & 2.578 & 1.799 \\
\hline$\mu\left(\mathrm{mm}^{-1}\right)$ & 1.601 & 12.735 & 1.692 \\
\hline$F(000)$ & 2288 & 1496 & 1424 \\
\hline
\end{tabular}




\begin{tabular}{llll}
$R_{1}$ & 0.0257 & 0.0311 & 0.0332 \\
$w R_{2}$ & 0.0637 & 0.0828 & 0.0786 \\
$\begin{array}{l}\text { Independent } \\
\text { reflections }\end{array}$ & 9868 & 3162 & 5113 \\
$2 \mho \leq\left(^{\circ}\right)$ & 55.086 & 50.140 & 50.484 \\
Parameters & 451 & 202 & 330 \\
Goodness of fit (S) & 1.126 & 0.812 & 1.294 \\
\hline
\end{tabular}

\section{References}

[1] H. Li, J. Wu, Z. Yin and H. Zhang, Acc. Chem. Res., 2014, 47, 1067-1075.

[2] X. Huang, Z. Y. Zeng and H. Zhang, Chem. Soc. Rev., 2013, 42, 1934-1946.

[3] D. Seyferth and A. M. Kiwan, J. Organomet. Chem., 1985, 281, 111-118; (b) Y.-C. Shi, H.-R. Cheng and D.-C. Cheng, Acta Cryst., 2013, C69, 581-583; (c) I. L. Eremenko, S. Rosenberger, S. E. Nefedov, H. Berke and V.M. Novotortsev, Inorg. Chem., 1995, 34, 830-840; (d) Y.-C. Shi, Y. Shi and W. Yang, J. Organomet. Chem., 2014, 772-773, 131-138; (e) R. D. Adams, S. Miao, M. D. Smith and H. Farach, Inorg. Chem., 2004, 43, 2515-2525; (f) P. Shupp, A. R. Rose and M. J. Rose, Dalton Trans., 2017, 46, 9163-9171; (g) P. Mathur, R. S. Ji, A. Raghuvanshi, Md. Tauqeer and S. M. Mobin, J. Organomet. Chem., 2017, 835, 31-38; (h) N. A. Pushkarevsky, A. V. Virovets, S. Gerber and S. N. Konchenko, Z. Anorg. Allg. Chem., 2007, 633, 2408-2413.

[4] A. Kornienko, J. H. Melman, G. Hall, T. J. Emge and J. G. Brennan, Inorg. Chem., 2002, 41, 121-126.

[5] J. M. Lalancette, A. Frêche and R. Monteux, Can. J. Chem., 1968, 46, 2754-2757; (b) J. M. Lalancette and M. Arnac, Can. J. Chem., 1969, 47, 3695-3697.

[6] R. Ramalakshmi, K. Saha, A. Paul and S. Ghosh, J. Chem. Sci., 2016, 128, 1025-1032. (b): K. Saha, S. Kar and S. Ghosh, J. Indian Chem. Soc., 2018, 95, 729.

[7] S. Kar, K. Saha, S. Saha, K. Bakthabachalam, V. Dorcet and S. Ghosh, Inorg. Chem., 2018, 57, 10896-10905.

[8] (a) S. Kar, S. Bairagi, K. Saha, B. Raghavendra, and S. Ghosh Dalton Trans., 2019, 48, 4203-4210. (b) S. K. Barik, M. G. Chowdhury, S. De, P. Parameswaran and S. Ghosh, Eur. J. Inorg. Chem., 2016, 2016, 4546-4550, (c) K. Saha, S. Kar and S. Ghosh, J. Indian Chem. Soc., 2018, 95, 729.

[9] S. Klose, U. Flörke and Hans Egold, Organometallics, 2003, 22, 3360-3366.

[10] R. S. Anju, K. Saha, B. Mondal, V. Dorcet, T. Roisnel, J.-F. Halet and S. Ghosh, Inorg. Chem., 2014, 53, 10527-10535.

[11] K. Saha, S. Kar, U. Kaur, T. Roisnel and S. Ghosh, Organometallics, 2020, 40, 529-538.

[12] L.-X. Cheng, C.-B. Ma, M.-Q. Hu and C.-N. Chen, Acta Cryst., 2005, E61, m892-m894.

[13] (a) K. Saha, U. Kaur, S. Kar, B. Mondal, B. Joseph, P. K. S. Antharjanam and S. Ghosh, Inorg. Chem., 2019, 58, 2346-2353; (b) J. Hu, G. Liu, Q. Jiang, R Zhang, W. Huang and H. Yan, Inorg. Chem. 2010, 49, 11199-11204.

[14] (a) S.-P. Huang and M. G. Kanatzidis, Inorg. Chem., 1993, 32, 821-825; (b) J.-P. Li and Y.-C. Shi, Inorg. Chim. Acta, 2018, 482, 77-84; (c) K. Chondroudis and M. G. Kanatzidis, Chem. Commun., 1997, 401-402; (d) C.-H. Ho, Y.-Y. Chu, C.-N. Lin, H.-W. Chen, C.-Y. Huang and M. Shieh, Organometallics, 2010, 29, 4396-4405.

[15] A. Lupan and R. B. King, Ch 1. Metal-Metal Multiple Bonding in Dimetallaboranes in Handbook of Boron Science (Ed.s N. S. Hosmane, R. Eagling), pp. 1-20, World Scientific (Europe), 2018.

[16] B. Rödl and R. Wolf, Chem. Eur. J., 2019, 25, 8332-8343.

[17] K. Pathak, R. Ramalakshmi, M. Zafar, S. Bagchi, T. Roisnel and S. Ghosh, ACS Omega, 2019, 4, 16651-16659. 
[18] B. S. Krishnamoorthy, A. Thakur, K. K. V. Chakrahari, S. K. Bose, P. Hamon, T. Roisnel, S. Kahlal, S. Ghosh and J.F. Halet, Inorg. Chem., 2012, 51, 10375-10383.

[19] (a)C. S. Day and D. E. Fogg, Organometallics, 2018, 37, 4551-4555; (b) J. Popp, S. Hanf and E. Hey-Hawkins, ACS Omega, 2019, 4, 22540-22548.

[20] S. K. Barik, C. E. Rao, K. Yuvaraj, R. Jagan, S. Kahlal, J.-F. Halet and S. Ghosh, Eur. J. Inorg. Chem., 2015, 55565562.

[21] B. Joseph, R. Prakash, K. Pathak, T. Roisnel, S. Kahlal, J.-F. Halet and S. Ghosh, New J. Chem., 2020, 44, 674-683.

[22] (a) K. Wade, J. Chem. Soc. D, 1971, 792-793; (b) K. Wade, Adv. Inorg. Chem. Radiochem., 1976, 18, 1-66; (c) M. A. Fox and K. Wade, Pure Appl. Chem., 2003, 75, 1315-1323.

[23] G. C. M'bitsi-Ibouily, T. Marimuthu, P. Kumar, Y. E. Choonara, L. C. Du. Toit, P. Pradeep, G. Modi and V. Pillay, Sci. Rep., 2019, 9:4146, 1-18.

[24] A. Gilewska, B. Barszcz, J. Masternak, K. Kazimierczuk, J. Sitkowski, J. Wietrzyk and E. Turlej, J. Biol. Inorg. Chem., 2019, 24, 591-606.

[25] G. Soras, N. Psaroudakis, M. J. Manos, A. J. Tasiopoulos, D. G. Liakos and G. A. Mousdis, Polyhedron, 2013, 62, 208-217.

[26] M. A. Bennett, T.-N. Huang, T. W. Matheson, A. K. Smith, S. Ittel and W. Nickerson, Inorg. Synth., 1982, 21, 7478.

[27] U. Koelle, J. Kossakowski, D. Grumbine and T. D. Tilley, Inorg. Synth., 2007, 29, 225-228.

[28] G. E. Ryschkewitsch and K. C. Nainan, Inorg. Synth., 1974, 15, 113-114.

[29] M. J. Frisch, G. W. Trucks, H. B. Schlegel, G. E. Scuseria, M. A. Robb, J. R. G. Cheeseman, B. Mennucci, G. A. Petersson, H. Nakatsuji, M. Caricato, X. Li Hratchian, H. P. Hratchian, A. F. Izmaylov, J. Bloino, G. Zheng, J. L. Sonnenberg, M. Hada, M. Ehara, K. Toyota, R. Fukuda, J. Hasegawa, M. Ishida, T. Nakajima, Y. Honda, O. Kitao, H. Nakai, T. Vreven, Jr. J. A. Montgomery, J. E. Peralta, F. Ogliaro, M. Bearpark, J. J. Heyd, E. Brothers, K. N. Kudin, V. N. Staroverov, T. Keith, R. Kobayashi, J. Normand, K. Raghavachari, A. Rendell, J. C. Burant, S. S. Iyengar, J. Tomasi, M. Cossi, N. Rega, J. M. Millam, M. Klene, J. E. Knox, J. B. Cross, V. Bakken, C. Adamo, J. Jaramillo, M.Millam, J. E. Klene, J. B. Knox, V. Cross, C. Bakken, J. Adamo, R. Jaramillo, R.Gomperts, R. E. Stratmann, O. Yazyev, A. J. Austin, R. Cammi, C. Pomelli, J. W. Ochterski, R. L. Martin, K. Morokuma, V. G. Zakrzewski, G. A. Voth, P. Salvador, J. J. Dannenberg, S. Dapprich, A. D. Daniels, O. Farkas, J. B. Foresman, J. V. Ortiz, J. Cioslowski and D. J. Fox. Gaussian 09, revision C.01; Gaussian Inc., Wallingford, CT, 2010.

[30] (a)F. London, J. Phys. Radium., 1937, 8, 397-409; (b) R. Ditchfield, Mol. Phys., 1974, 27, 789-807; (c) K. Wolinski, J. F. Hinton, P. Pulay, J. Am. Chem. Soc., 1990, 112, 8251-8260.

[31] A. D. Becke, Phys. Rev. A., 1988, 38, 3098-3100; (b) C. Lee, W. Yang, R. G. Parr, Phys. Rev. B., 1988, 37, 785-789; (c) A. D. Becke, J. Chem. Phys., 1993, 98, 5648-5652.

[32] T. P. Onak, H. L. Landesman, R. E. Williams, I. Shapiro, J. Phys.Chem., 1959, 63, 1533-1535.

[33] (a) E. D. Glendening, A. E. Reed, J. E. Carpenter, F. Weinhold, NBO Program 3.1, W. T. Madison, 1988; (b) A. E. Reed, F. Weinhold, L. A. Curtiss, Chem. Rev., 1988, 88, 899-926; (c) F. Weinhold, R. Landis, Valency and bonding:A natural bond orbital donor-acceptor perspective; Cambridge University Press: Cambridge; U.K, 2005.

[34] R. F. W. Bader, Atoms in Molecules: a Quantum Theory; Oxford University Press: Oxford, U.K., 1990; (b) R. F. W. Bader, J. Phys. Chem. A., 1998, 102, 7314-7323; (c) R. F. W. Bader, Chem. Rev., 1991, 91, 893-928.

[35] T. Lu, F. Chen, J. Comput. Chem., 2012, 33, 580-592.

[36] (a) I. Dennington, R. T. Keith, J. Millam, K. Eppinnett, W. L. Hovell, R. Gilliland, GaussView, Version 3.09; Semichem Inc.: Shawnee Mission, KS, 2003.

[37] G. A. Zhurko, http://www.chemcraftprog.com.

[38] G. M. Sheldrick, Acta Crystallogr. Sect., C 2015, 71, 3-8. 
[39] A. Altomare, G. Cascarano, C. Giacovazzo, A. Guagliardi, M. C. Burla, G. Polidori and M. Camalli, J. Appl. Crystallogr., 1994, 27, 435-436.

[40] O. V. Dolomanov, L. J. Bourhis, R. J. Gildea, J. A. K. Howard and H. Puschmann, J. Appl. Cryst., 2009, 42, 339341. 


\section{Table of Content Entry Only}

Stabilization of dichalcogenide ligand/s in tetraruthenium and bis-/trishomocubane cores (see picture).

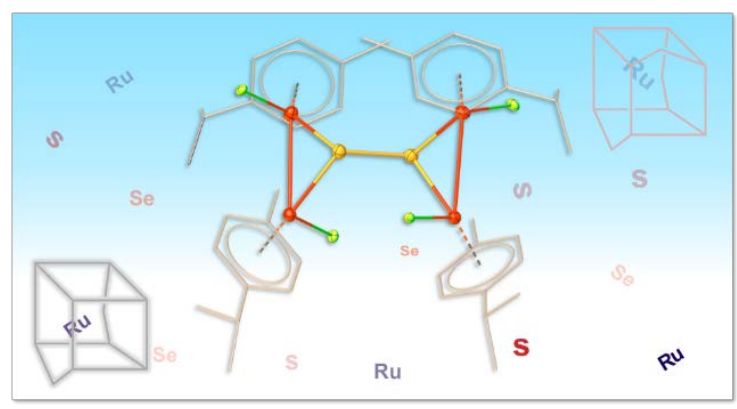

